\title{
Impacts of aircraft emissions on the air quality near the ground
}

\author{
H. Lee ${ }^{1,2}$, S. C. Olsen ${ }^{1}$, D. J. Wuebbles ${ }^{1}$, and D. Youn ${ }^{3}$ \\ ${ }^{1}$ Department of Atmospheric Sciences, University of Illinois, Urbana, IL, USA \\ ${ }^{2}$ Jet Propulsion Laboratory, California Institute of Technology, Pasadena, CA, USA \\ ${ }^{3}$ Department of Earth Science Education, Chungbuk National University, Cheongju, South Korea \\ Correspondence to: H. Lee (midatm123@naver.com)
}

Received: 30 November 2012 - Published in Atmos. Chem. Phys. Discuss.: 8 January 2013

Revised: 17 April 2013 - Accepted: 30 April 2013 - Published: 6 June 2013

\begin{abstract}
The continuing increase in demand for commercial aviation transport raises questions about the effects of resulting emissions on the environment. The purpose of this study is to investigate, using a global chemistry transport model, to what extent aviation emissions outside the boundary layer influence air quality in the boundary layer. The large-scale effects of current levels of aircraft emissions were studied through comparison of multiple simulations allowing for the separated effects of aviation emissions occurring in the low, middle and upper troposphere. We show that emissions near cruise altitudes (9-11 km in altitude) rather than emissions during landing and take-off are responsible for most of the total odd-nitrogen $\left(\mathrm{NO}_{\mathrm{y}}\right)$, ozone $\left(\mathrm{O}_{3}\right)$ and aerosol perturbations near the ground with a noticeable seasonal difference. Overall, the perturbations of these species are smaller than $1 \mathrm{ppb}$ even in winter when the perturbations are greater than in summer. Based on the widely used air quality standards and uncertainty of state-of-the-art models, we conclude that aviation-induced perturbations have a negligible effect on air quality even in areas with heavy air traffic. Aviation emissions lead to a less than $1 \%$ aerosol enhancement in the boundary layer due to a slight increase in ammonium nitrate $\left(\mathrm{NH}_{4} \mathrm{NO}_{3}\right)$ during cold seasons and a statistically insignificant aerosol perturbation in summer. In addition, statistical analysis using probability density functions, Hellinger distance, and $p$ value indicate that aviation emissions outside the boundary layer do not affect the occurrence of extremely high aerosol concentrations in the boundary layer. An additional sensitivity simulation assuming the doubling of surface ammonia emissions demonstrates that the
\end{abstract}

aviation induced aerosol increase near the ground is highly dependent on background ammonia concentrations whose current range of uncertainty is large.

\section{Introduction}

The United States Federal Aviation Administration (FAA) recently forecasts an increase in passenger aviation transport by $60 \%$ over the next 20 years (FAA, 2012). This rapid increase in demand for aviation traffic has brought further attention to the effects of aviation emissions on climate, air quality, and noise pollution.

Aviation activities contribute to climate change through emissions of carbon dioxide $\left(\mathrm{CO}_{2}\right)$, nitrogen oxides $\left(\mathrm{NO}_{\mathrm{x}}\right)$, volatile organic compounds (VOC), sulfur dioxide $\left(\mathrm{SO}_{2}\right)$, water vapor $\left(\mathrm{H}_{2} \mathrm{O}\right)$, soot and other particles to the atmosphere (Brasseur et al., 1996; IPCC, 1999; Lee et al., 2010). Since a large proportion of these emissions occurs near cruise altitudes at roughly $9-11 \mathrm{~km}$, many studies have focused on the resulting climate effects of aviation emissions in the upper troposphere and lower stratosphere (e.g., Brasseur et al., 1998; Hendricks et al., 2000, Morris et al., 2003, Lee et al., 2010).

Most studies of the potential effects of aviation on local air quality in the boundary layer have focused on emissions near major airports. Previous studies have shown a strong relationship between emissions during the landing and takeoff (LTO) cycle below $1000 \mathrm{~m}$ altitude and air quality near 
airports (Herndon et al., 2004; Schurmann et al., 2007; Herndon et al., 2008).

Tarrason et al. (2004) found that the emission by aircraft during climb/descent and during cruise, the so called nonLTO emissions occurring above $1 \mathrm{~km}$ in altitude, can have a larger impact than LTO emissions on air quality in Europe because of the relatively large amount of non-LTO emissions compared to LTO emissions. A recent study (Barrett et al., 2010) also raises an interesting issue, suggesting that current non-LTO aviation emissions may adversely affect local air quality throughout the world, particularly increasing the amount of atmospheric particulates, especially small particles less than $2.5 \mu \mathrm{m}$ in diameter $\left(\mathrm{PM}_{2.5}\right)$. Particulate matter (PM) includes both liquid and solid particles whose composition is highly variable. Cohen et al. (2005) has shown that higher concentrations of $\mathrm{PM}_{2.5}$ between 7.5 and $50 \mu \mathrm{g} \mathrm{m}^{-3}$ could result in more cardiopulmonary deaths. As a result, in their study of aviation emissions, Barrett et al. (2010) concluded that secondary aerosols such as sulfate-ammoniumnitrate formed by $\mathrm{NO}_{\mathrm{x}}$ and $\mathrm{SO}_{\mathrm{x}}$ emissions from aircraft can be critical to increasing levels of premature deaths, by about 8000 per year worldwide.

The Barrett et al. (2010) study brings to light several important points that deserve further investigation. For example, the time scale of vertical mixing from cruise altitudes to the boundary layer is longer than the lifetime of chemicals affected by non-LTO emissions (Whitt et al., 2011). So it is questionable that sinking motions in the mean general circulation of the atmosphere can effectively transport aircraft emissions down to the ground as suggested in Barrett et al. (2010). In addition, it is the frequent occurrence of higher aerosol concentration than the regulation standards, e.g., $35 \mu \mathrm{g} \mathrm{m}^{-3}$ as a daily average in the US (EPA, 2006), that most affects human health, rather than a slight increase in background PM. For example, the World Health Organization provides $25 \mu \mathrm{g} \mathrm{m}^{-3}$ of daily mean $\mathrm{PM}_{2.5}$ as an acceptable guideline for minimizing health effects. So the main findings of Barrett et al. (2010), the mortality attributable to the small increase of mean $\mathrm{PM}_{2.5}$ in places where background $\mathrm{PM}_{2.5}$ is lower than the guideline values, needs to be further examined.

The main objective of this study is to evaluate effects of emissions from aircraft on air quality by comparing multiple simulations from a chemistry transport model with and without aircraft emissions. We evaluated the aviationinduced perturbations of gases and aerosols in the boundary layer. However, as discussed in Lin et al. (2008), our model's horizontal resolution is too coarse to simulate boundary layer ozone in some regions with large subgridcell heterogeneity. In addition, impacts of aviation emissions in sub-grid scale, such as highly concentrated ground emissions near major airports, are averaged over the entire grid cell area. Therefore, for this study we focused on the large-scale impacts of non-LTO aircraft emissions by analyzing ozone $\left(\mathrm{O}_{3}\right)$, total odd-nitrogen $\left(\mathrm{NO}_{\mathrm{y}}\right)$ and
$\mathrm{PM}_{2.5}$ defined as the total mass mixing ratio of sulfate, ammonium nitrate $\left(\mathrm{NH}_{4} \mathrm{NO}_{3}\right)$, organic carbon $(\mathrm{OC})$, and black carbon (BC) particles. In this study, $\mathrm{NO}_{\mathrm{y}}$ is defined as the sum of related gaseous reactive nitrogen containing species, $\mathrm{N}+\mathrm{NO}+\mathrm{NO}_{2}+\mathrm{NO}_{3}+\mathrm{HNO}_{3}+\mathrm{HO}_{2} \mathrm{NO}_{2}+2$ $\times \mathrm{N}_{2} \mathrm{O}_{5}+\mathrm{CH}_{3} \mathrm{CO}_{3} \mathrm{NO}_{2}(\mathrm{PAN})+\mathrm{CH}_{3} \mathrm{COCH}_{2} \mathrm{ONO}_{2}$ (organic nitrate) $+\mathrm{CH}_{2} \mathrm{CCH}_{3} \mathrm{CO}_{3} \mathrm{NO}_{2}$ (MPAN, methacryloyl peroxynitrate) $+\mathrm{CH}_{2} \mathrm{CHCCH}_{3} \mathrm{OOCH}_{2} \mathrm{ONO}_{2}$ (ISOPNO3, peroxy radical from $\mathrm{NO}_{3}+$ isoprene) $+\mathrm{CH}_{2} \mathrm{CCH}_{3} \mathrm{CHONO}_{2} \mathrm{CH}_{2} \mathrm{OH}$ (lumped isoprene nitrates). Nitrous oxide is not included in $\mathrm{NO}_{\mathrm{y}}$ because of its long atmospheric lifetime.

Our study goes beyond just evaluating previous findings using a different set of a model and emission database. First of all, we considered the seasonality of aviation effects on both gases and aerosols rather than focusing on annual averages. Collins et al. (1997) has shown that during wintertime, in regions of high $\mathrm{NO}_{\mathrm{x}}$, increased $\mathrm{NO}_{\mathrm{x}}$ emissions actually decrease $\mathrm{O}_{3}$ as there is more titration of $\mathrm{O}_{3}$ with $\mathrm{NO}_{x}$ than production of $\mathrm{O}_{3}$. We evaluate whether this holds for the added $\mathrm{NO}_{\mathrm{x}}$ emissions from aviation. Secondly, we examine the role of free ammonia $\left(\mathrm{NH}_{3}\right)$, an important gas in aerosol formation, in aviation effects on air quality. Higher $\mathrm{NH}_{3}$ is a critical condition to produce more aerosols and the formation of $\left(\mathrm{NH}_{4}\right)_{2} \mathrm{SO}_{4}$ is always prioritized over formation of $\mathrm{NH}_{4} \mathrm{NO}_{3}$ (Seinfeld and Pandis, 2006). Although the equilibrium state and equilibrium constant to produce aerosols are also determined by the local temperature and relative humidity, the concentration of $\mathrm{NH}_{3}$ is the most important key factor under similar meteorological conditions (Nowak et al., 2010). Finally, we adopt a statistical tool that is useful to quantitatively scrutinize the differences between two probability density functions. The resulting analysis enables us to make meaningful conclusions on the localized effects of aviation emissions impacts on occurrence of extremely high aerosol levels in regions with high air traffic.

The remainder of this paper is structured as follows. The data and model used in this study are described in Sect. 2. Comparisons between the different model simulations and analyses are presented in Sect. 3 followed by a summary of key findings in Sect. 4.

\section{Data and model}

The aviation emissions data used in this study were provided by Steven Baughcum of the Boeing Company (Baughcum et al., 1998; Sutkus et al., 2001). This data is generated considering scheduled air traffic, general aviation and charter flights for the year 1999 (Olsen et al., 2013) with vertical resolution of $1 \mathrm{~km}$. In this study, $\mathrm{NO}_{\mathrm{x}}, \mathrm{CO}, \mathrm{SO}_{2}, \mathrm{BC}$, and $\mathrm{OC}$ emissions from aircraft were used. For simplicity, all black carbon and organic carbon aerosols from aircraft were assumed to be hydrophilic. We will validate this assumption later. In addition, we used annual average emissions as input to our simulations. The diurnal cycle and seasonal variation 
Table 1. The total annual emissions from aircraft used in this study. Unit of the emissions is $\mathrm{Tg}$ (teragram)/year. LTO emissions are defined as the emissions occurring at or below $1 \mathrm{~km}$ altitude and cruise altitude emissions are defined emissions at or above $9 \mathrm{~km}$. Emissions between $1 \mathrm{~km}$ and $9 \mathrm{~km}$ are designated climb/descent emissions.

\begin{tabular}{|c|c|c|c|c|c|}
\hline units: [Tg $\left.\mathrm{yr}^{-1}\right]$ & $\begin{array}{l}\mathrm{NO}_{\mathrm{x}} \\
\text { (as NO) }\end{array}$ & $\mathrm{CO}$ & $\mathrm{SO}_{2}$ & black carbon & organic carbon \\
\hline LTO emissions & $\begin{array}{l}0.126 \\
(9.5 \%)\end{array}$ & $\begin{array}{l}0.624 \\
(37.3 \%)\end{array}$ & $0.0167(10.3 \%)$ & $0.00134(19.9 \%)$ & 0.000446 \\
\hline climb/descent emissions & $\begin{array}{l}0.489 \\
(36.9 \%)\end{array}$ & $\begin{array}{l}0.732 \\
(43.8 \%)\end{array}$ & $0.0518(32.0 \%)$ & $0.00296(44.1 \%)$ & 0.000985 \\
\hline cruise altitude emissions & $\begin{array}{l}0.712 \\
(53.7 \%)\end{array}$ & $\begin{array}{l}0.315 \\
(18.8 \%)\end{array}$ & $0.0931(57.6 \%)$ & $0.00242(36 \%)$ & 0.000805 \\
\hline total emissions & 1.347 & 1.692 & 0.164 & 0.007 & 0.002 \\
\hline
\end{tabular}

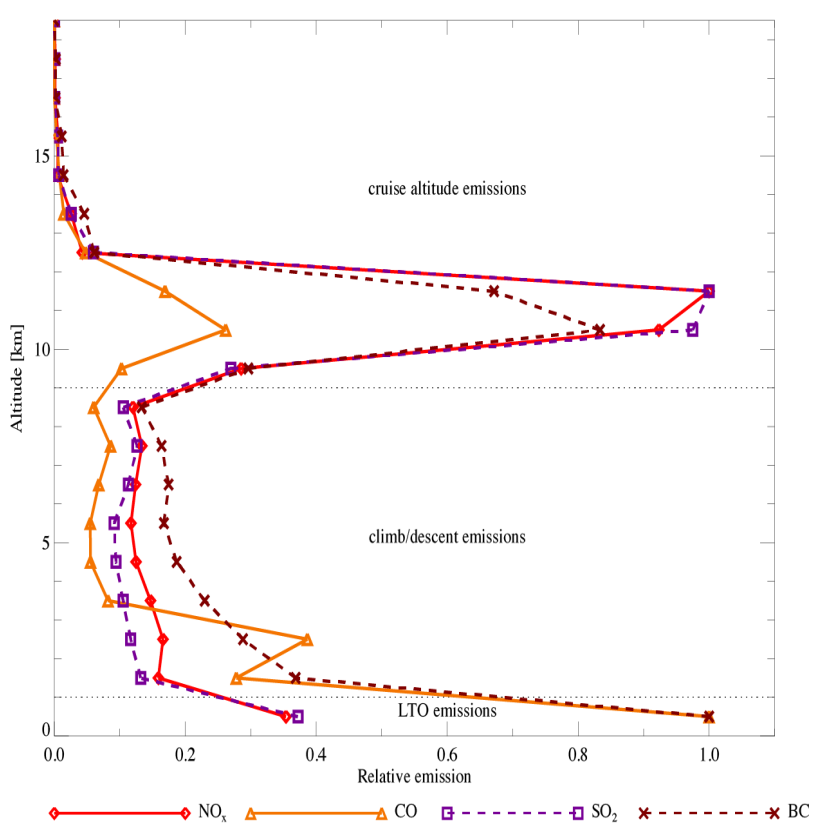

Fig. 1. A vertical profile of the total annual emissions of $\mathrm{NO}_{\mathrm{x}}$ (red solid), $\mathrm{CO}$ (orange solid), $\mathrm{SO}_{2}$ (purple dashed) and black carbon (brown dashed) from aircraft emission database representing 1999. The emission data is provided by Boeing company.

of aviation emissions are ignored in our approach. So any difference shown in our results between different seasons is caused by seasonally varying dynamics and chemical environment. The emissions of $\mathrm{SO}_{2}$ and aerosols were estimated using fuel burn rate and the emission indices are the same as those used by the Aerosol Comparisons between Observations and Models (AeroCom) (Textor et al., 2006). The hydrophilic aerosol assumption was also applied in AeroCom. Considering that $\mathrm{BC}$ is primarily emitted as a result of incomplete combustion mostly during landing and take-off, we used altitude dependent emission index (EI) for BC emissions rather than fixed value $(0.04 \mathrm{~g}$ per $1 \mathrm{~kg}$ of fuel $)$ in Barrett et al. (2010). The emission of OC is simply assumed as
$1 / 3$ of the $\mathrm{BC}$ emission. Our analyses of $\mathrm{PM}_{2.5}$ exclude fine dust and sea salts assuming that impacts of aviation emissions on them are negligible. It should be noted that $\mathrm{OC}$ and $\mathrm{BC}$ perturbations are highly dependent on emission indices which have large uncertainties and dependence on flight altitudes (EPA, 2012).

The total annual emissions from aircraft are shown in Table 1 and the relative proportion of emissions at each altitude is plotted in Fig. 1. Overall, most of the $\mathrm{NO}_{\mathrm{x}}$ emissions occur near cruise altitudes, whereas considerable amounts of $\mathrm{CO}$ and $\mathrm{BC}$ are emitted during the LTO cycle. In terms of the total emissions, these emission data show very close agreement with the data used by Tarrason et al. (2004). The non-LTO fraction of aerosols in this study is about $80 \%$ of the total emissions as in Tarrason et al. (2004). However, the non-LTO emissions of $\mathrm{NO}_{\mathrm{x}}$ and $\mathrm{CO}$ account for a higher proportion of the total emissions than those in Tarrason et al. (2004).

Recently, Olsen et al. (2013) reported that the fuel burn from commercial aircraft increased by $71 \%$ between 1992 and 2006. Considering the rapid increase in aviation emissions during the past decade, we additionally evaluated the aviation effect on $\mathrm{PM}_{2.5}$ using aviation $\mathrm{NO}_{\mathrm{x}}$ emissions data from the Federal Aviation Administration/Aviation Environmental Design Tool (FAA/AEDT) for the year 2006 (Wilkerson et al., 2010; Olsen et al., 2013). Overall the spatial distribution of the FAA/AEDT emissions is similar to that of Boeing emissions for 1999 but the FAA/AEDT $\mathrm{NO}_{\mathrm{x}}$ emissions are about $30 \%$ larger than the Boeing $\mathrm{NO}_{\mathrm{x}}$ emissions.

Model simulations using the chemistry version of global Community Atmosphere Model (CAM-chem) version 3.4.13 (Lamarque et al., 2005) were carried out to examine differences in $\mathrm{O}_{3}, \mathrm{NO}_{\mathrm{y}}$ and aerosols as a result of aircraft emissions. The model considers full chemistry of troposphere and stratosphere and simulates aerosols using a bulk aerosol model. The same model was used to assess air quality issues related to surface ozone and aerosols for the present and future (Lei et al., 2012). Also, intercomparison of multiple global chemistry models shows that this model reasonably reproduces the effects of aviation emissions on distributions of key tracers such as $\mathrm{O}_{3}$ and $\mathrm{NO}_{\mathrm{x}}$ (Weber, 2011). CAM- 
(a) January
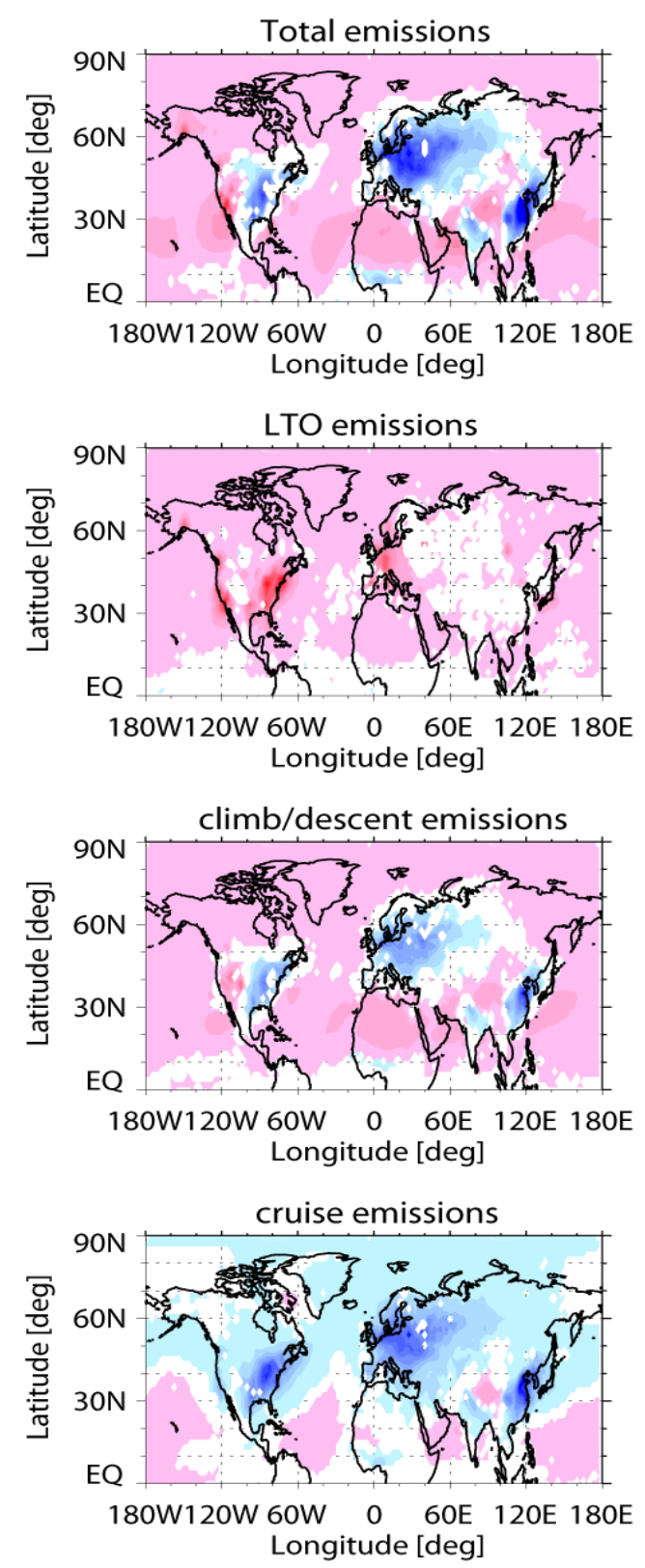

(b) July
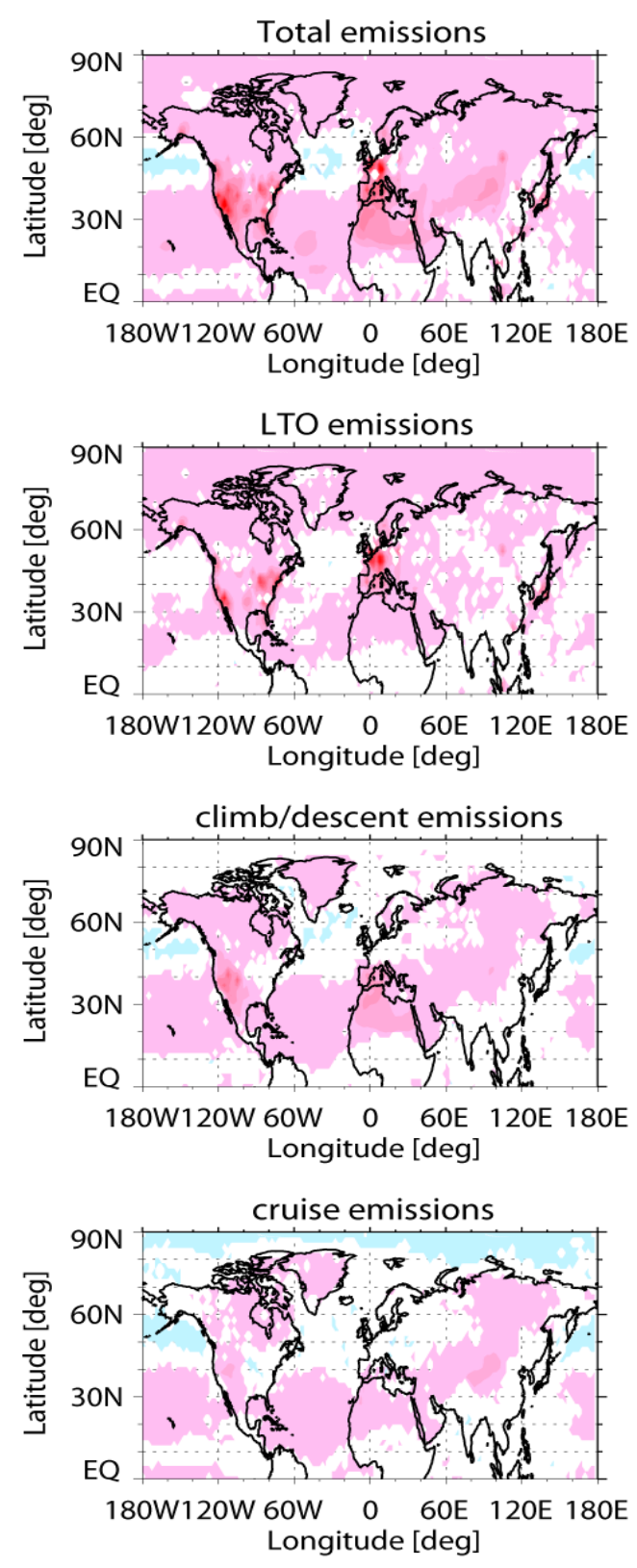

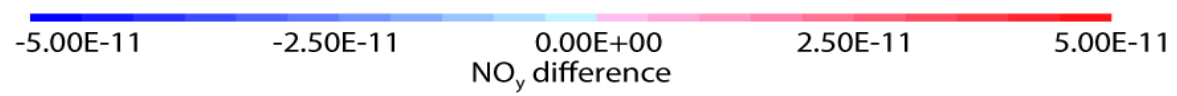

Fig. 2. Differences in the boundary layer $\mathrm{NO}_{\mathrm{y}}$ volume mixing ratio between the baseline control and the simulation with aircraft emissions (ALL-CTRL) in (a) January (left column) and (b) July (right column). From top to bottom, [top] (ALL-CTRL: the perturbations due to the total aviation emissions), (ALL-nonLTO: the perturbations due to emissions occurring at or below $1 \mathrm{~km}$ ), (nonLTO-CRUISE: the perturbations due to emissions occurring between 2 and $8 \mathrm{~km}$ ) and [bottom] (CRUISE-CTRL).

chem has 26 vertical levels covering up to $3.5 \mathrm{hPa}$, with the horizontal resolution of approximately a $2.5^{\circ}$ (longitude) $\times 2.0^{\circ}$ (latitude). In CAM-chem, the modules controlling production of ammonium aerosols are based on Seinfeld and Pandis (2006). The meteorological fields for running CAM- chem were prepared as follows. First of all, we ran CAMchem for six model years with interactive meteorology and chemistry. Then the meteorological fields from the 6th year were extracted every six hours to drive CAM-chem in an offline mode. Table 2 summarizes the six model simulations 
Table 2. List of simulations and aviation emission data used for each simulation. CTRL and CTRL_2 $\mathrm{xNH}_{3}$ simulations do not include any aviation emissions. Other cases consider relevant parts of the aviation emissions to separate the effects of LTO and non-LTO emissions from the total emissions.

\begin{tabular}{llll}
\hline Case & $\begin{array}{l}\text { LTO emissions } \\
(0-1 \mathrm{~km})\end{array}$ & $\begin{array}{l}\text { Climb/descent } \\
\text { emissions } \\
(2-8 \mathrm{~km})\end{array}$ & $\begin{array}{l}\text { Cruise altitude } \\
\text { emissions } \\
(\text { above } 9 \mathrm{~km})\end{array}$ \\
\hline CTRL & No & No & No \\
ALL & Yes & Yes & Yes \\
nonLTO & No & Yes & Yes \\
CRUISE & No & No & Yes \\
CTRL_2 $\mathrm{NH}_{3}$ & No & No & No \\
$\begin{array}{l}\text { double } \mathrm{NH}_{3} \\
\text { flux })\end{array}$ & & & \\
$\begin{array}{l}\text { ALL_2 } 2 \times \mathrm{NH}_{3} \\
\left(\text { double } \mathrm{NH}_{3}\right.\end{array}$ & Yes & Yes & Yes \\
flux $)$ & & & \\
\hline
\end{tabular}

for investigating aircraft impacts from each altitude range and the model's sensitivity to $\mathrm{NH}_{3}$ flux from the ground. Most of the ground emissions used in CAM-chem are from the Precursors of Ozone and their Effects in the Troposphere (POET) database, but the $\mathrm{NH}_{3}$ emissions of EDGAR2 database are used for CAM-chem due to lack of $\mathrm{NH}_{3}$ in POET (Lamarque et al., 2012). The first four runs consist of runs without aviation emissions (CTRL), with all aircraft emission (ALL), with aircraft emissions excluding LTO emissions (nonLTO) and with only emissions at cruise altitudes (CRUISE). Contributions from LTO phases are estimated as difference between two runs (ALL - nonLTO). The last two simulations are the same as ALL and CTRL simulations except for the doubled $\mathrm{NH}_{3}$ flux assumption at the surface.

For comparison of the results, we focused on the monthly averaged fields made with daily averaged outputs in January and July as representative months of winter and summer, respectively. When building a probability density function (PDF), daily mean data of each grid point in the entire targeted area were used. To represent the planetary boundary layer, the fields at the lowest model level were used. The average of the lowest three model levels $(993,971$ and $930 \mathrm{hPa}$ in reference pressure levels) does not show any significant difference relative to using only values at the lowest level of the model.

\section{Results}

\subsection{Changes in gases $\left(\mathrm{NO}_{\mathrm{y}}\right.$ and $\left.\mathrm{O}_{3}\right)$}

High concentrations of $\mathrm{NO}_{y}$ and $\mathrm{O}_{3}$ can result in adverse health effects. Especially the $\mathrm{O}_{3}$ level in summer is a major issue in air pollution. In order to examine the $\mathrm{NO}_{\mathrm{y}}$ and $\mathrm{O}_{3}$ perturbations in the boundary layer due to aviation emissions, we subtracted the baseline control run without aircraft emissions (CTRL) from the result with the full or partial aircraft emissions. Only statistically valid perturbations at $95 \%$ confidence level according to the student $\mathrm{t}$-test for paired samples are shown. Figure 2 clearly shows that the small decreases of $\mathrm{NO}_{\mathrm{y}}$ in the boundary layer in January, results mostly from non-LTO emissions when the effects of the total aviation emissions are compared to those of LTO, ascending/descending and cruise altitude emissions. LTO emissions occurring below $1 \mathrm{~km}$ increase $\mathrm{NO}_{\mathrm{y}}$ by a small amount in January, whereas emissions at cruise altitudes decrease $\mathrm{NO}_{\mathrm{y}}$ near the surface. In July, the overall $\mathrm{NO}_{\mathrm{y}}$ perturbation is smaller than in January and there are $\mathrm{NO}_{\mathrm{y}}$ increases due to the total aircraft emissions. The $\mathrm{NO}_{\mathrm{y}}$ increase in most midlatitudes continental regions is less than $0.3 \%$ due to the higher background $\mathrm{NO}_{\mathrm{y}}$, and the increase is smaller than that over the oceans.

It is interesting that the $\mathrm{NO}_{\mathrm{y}}$ on the US East Coast, Europe and East Asia decreases by up to $0.05 \mathrm{ppb}$ in January. These $\mathrm{NO}_{\mathrm{y}}$ decreases correspond to about $1-2 \%$ of the total background $\mathrm{NO}_{\mathrm{y}}$. It should be noted that these regions showing the negative $\mathrm{NO}_{\mathrm{y}}$ perturbations commonly have relatively higher background $\mathrm{NO}_{\mathrm{y}}$ concentration during cold seasons. The relevant reactions are (Collins et al., 1997).

$$
\begin{aligned}
& \mathrm{NO}_{2}+\mathrm{O}_{3} \rightarrow \mathrm{NO}_{3} \\
& \mathrm{NO}_{3}+\mathrm{NO}_{2} \rightarrow \mathrm{N}_{2} \mathrm{O}_{5} \\
& \mathrm{~N}_{2} \mathrm{O}_{5}+\mathrm{H}_{2} \mathrm{O} \rightarrow 2 \mathrm{HNO}_{3}
\end{aligned}
$$

Above reactions are dominant at nighttime especially in winter due to the short lifetime of $\mathrm{NO}_{3}$ under sunlight. The net reaction of (R1)-(R3) becomes

$2 \mathrm{NO}_{2}+\mathrm{O}_{3}+\mathrm{H}_{2} \mathrm{O}(\mathrm{s}) \rightarrow 2 \mathrm{HNO}_{3}$

Clearly, (R4) can be a more efficient sink for $\mathrm{NO}_{\mathrm{x}}$ than $\mathrm{O}_{3}$ because of two $\mathrm{NO}_{2}$ molecules reacting with one $\mathrm{O}_{3}$ molecule. 
(a) January
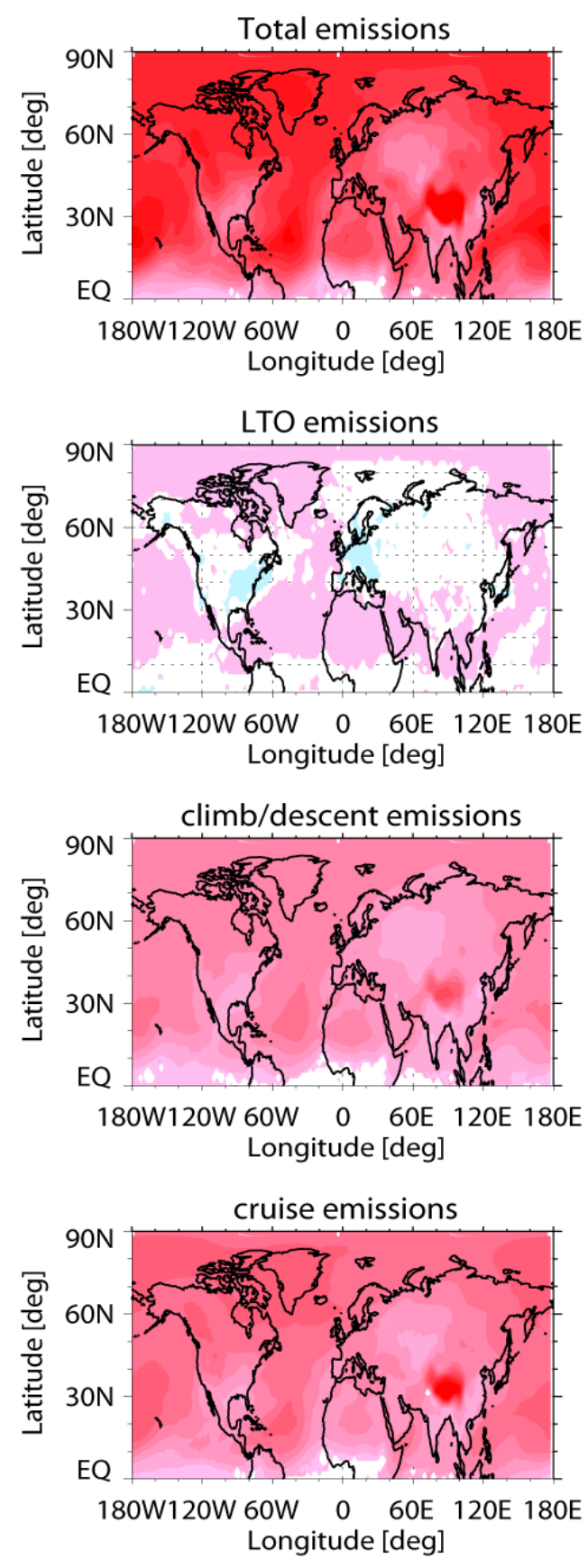

(b) July
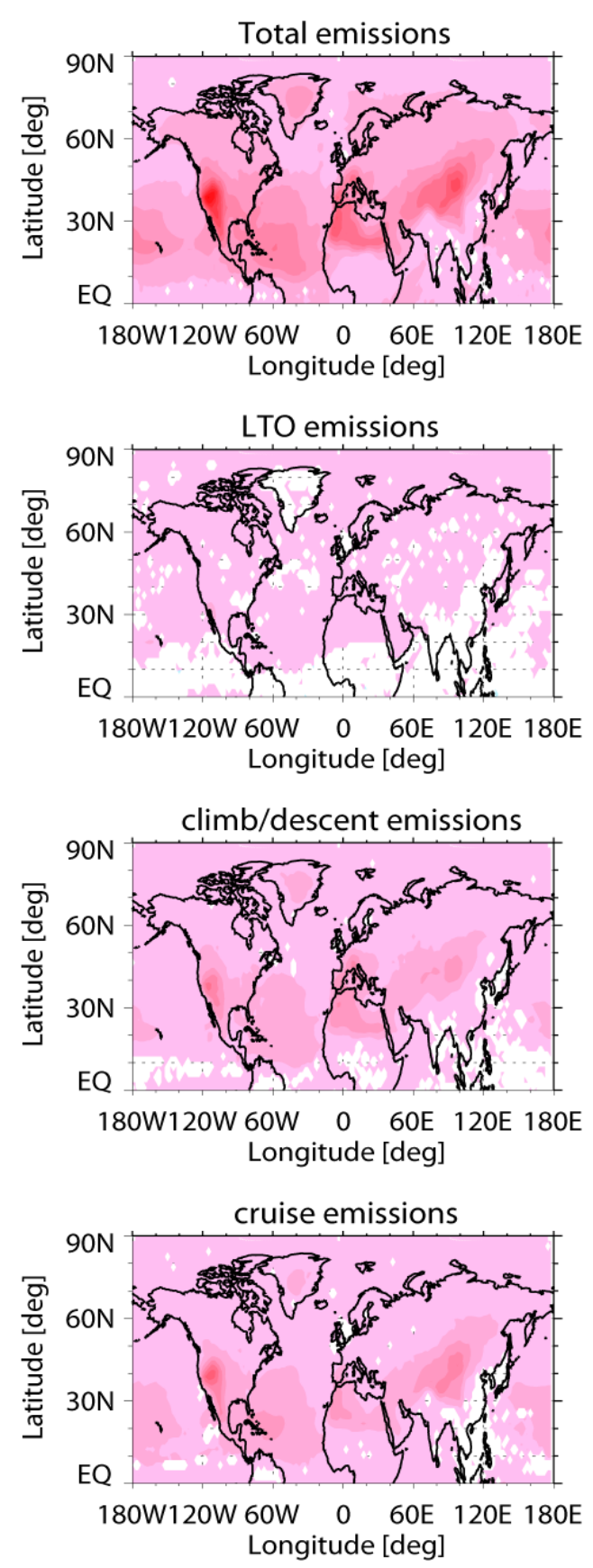

\begin{tabular}{|c|c|c|c|}
\hline$-1.00 \mathrm{E}-09$ & $-5.00 \mathrm{E}-10$ & $\begin{array}{r}0.00 \mathrm{E}+00 \\
\text { difference }\end{array}$ & $5.00 \mathrm{E}-10$ \\
\hline
\end{tabular}

Fig. 3. Same as Fig. 2 but for $\mathrm{O}_{3}$.

As shown later in Figs. 6 and 7, the perturbation of $\mathrm{O}_{3}$ due to aviation emissions is larger than that of $\mathrm{NO}_{\mathrm{x}}$ in the boundary layer. As a result, the increased $\mathrm{O}_{3}$ caused by non-LTO emissions consumes background $\mathrm{NO}_{2}$ via (R4), i.e., back- ground $\mathrm{NO}_{\mathrm{x}}$ is decreased, but $\mathrm{HNO}_{3}$ is increased by the $\mathrm{O}_{3}$ perturbation propagating from the upper troposphere. However, this $\mathrm{NO}_{\mathrm{y}}$ decrease is ignorable in view of the air quality so it is beyond the scope of this study. In summer, rather than 
(a) January

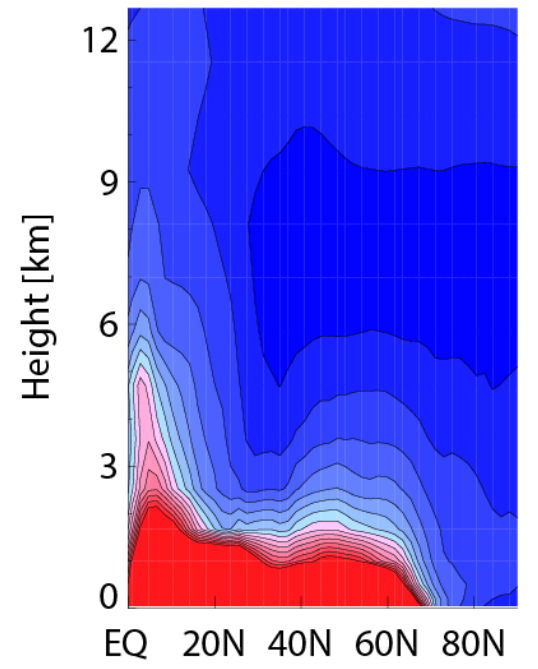

(b) July

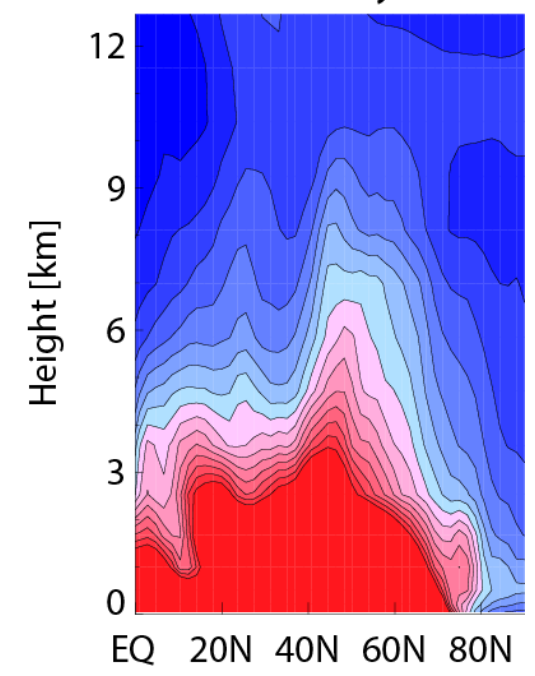

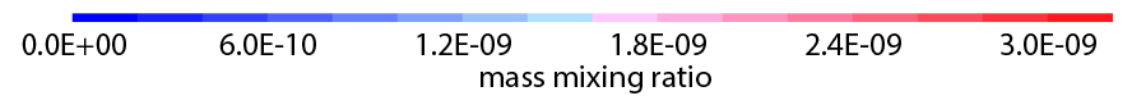

Fig. 4. Latitude-altitude distribution of monthly averaged mass mixing ratios of $\mathrm{PM}_{2.5} \cdot \mathrm{PM}_{2.5}$ was averaged over longitude between $0{ }^{\circ} \mathrm{E}$ and $90^{\circ} \mathrm{E}$ in (a) January (left) and (b) July (right).

(R1)-(R3), relatively abundant hydroxyl radical $(\mathrm{OH})$ leads the removal process of $\mathrm{NO}_{\mathrm{x}}$.

In contrast to $\mathrm{NO}_{y}$, Fig. 3 shows consistent $\mathrm{O}_{3}$ increases due to aircraft emissions. These results are for the short-term $\mathrm{O}_{3}$, which overestimate the aircraft impacts since they do not take into account the longer-term $\mathrm{O}_{3}$ reduction tied to the aviation induced methane decrease that are not represented in this study. Not surprisingly, the $\mathrm{O}_{3}$ increase in the Northern Hemisphere is several factors higher than in the Southern Hemisphere (not shown here), reflecting heavier air traffic in the Northern Hemisphere. The perturbations of $\mathrm{O}_{3}$ are up to several ppb in January and $0.5 \mathrm{ppb}$ in July. Both the total and non-LTO aircraft emissions increase boundary layer $\mathrm{O}_{3}$ about three times more in January than in July. The largest $\mathrm{O}_{3}$ increases in January are shown in the Eastern US (more than $2 \mathrm{ppb}$ ), East Asia (1.1 ppb) and Europe (1 ppb). However, considering the low background $\mathrm{O}_{3}$ concentration in winter relative to the EPA guideline ( 75 ppbv as daily 8 hours maximum average concentration), these perturbations are not important for local air quality. It should be kept in mind that the $\mathrm{O}_{3}$ in these three regions are limited by titration of high background $\mathrm{NO}_{\mathrm{x}}$ in January. Also, the impacts of non-LTO emissions (ascending/descending and cruise emissions) are greater than LTO emissions for the $\mathrm{O}_{3}$ perturbation both in January and July. This result is consistent with that of Tarrason et al. (2004) for the summer $\mathrm{O}_{3}$ increase due to non-LTO emissions.
Whereas previous studies (Tarrason et al., 2004; Barrett et al., 2010) focused only on summer perturbations or annual averages, our analyses indicate that non-LTO emissions result in distinct differences in $\mathrm{O}_{3}$ and $\mathrm{NO}_{y}$ perturbations between summer and winter. As mentioned previously, the aviation emission data used in this study do not have seasonal variations. There are some important factors likely causing the seasonal difference between January and July. One is the difference in solar radiation which determines the rates of photo-dissociation and lifetimes of $\mathrm{O}_{3}$ and $\mathrm{NO}_{\mathrm{y}}$. However, weaker shortwave radiation in winter cannot explain the stronger perturbations of $\mathrm{O}_{3}$ and $\mathrm{NO}_{\mathrm{y}}$ in the boundary layer. Another is a set of heterogeneous reactions occurring on the surface of aerosols.

Figure 4 shows the monthly averaged mass mixing ratio of background $\mathrm{PM}_{2.5}$ from "CTRL" simulation for January and July. The $\mathrm{PM}_{2.5}$ was zonally averaged for a longitude range of $0^{\circ} \mathrm{E}-90^{\circ} \mathrm{E}$ to cover Europe. Since the lifetime of $\mathrm{PM}_{2.5}$ is short and most aerosols are emitted from the surface, aerosol mass mixing ratios decrease drastically with altitude. In July (Fig. 4b), a thicker mixing layer and more frequent convection account for higher concentrations of aerosols in the middle troposphere compared to January (Fig. 4a). Thus, in summer, reactions occurring on the surface of hydrophilic aerosols (sulfate, $\mathrm{NH}_{4} \mathrm{NO}_{3}$, hydrophilic carbon and secondary organic aerosols) might become more 


\section{$\mathrm{NO}_{x}$ difference}

(a) January

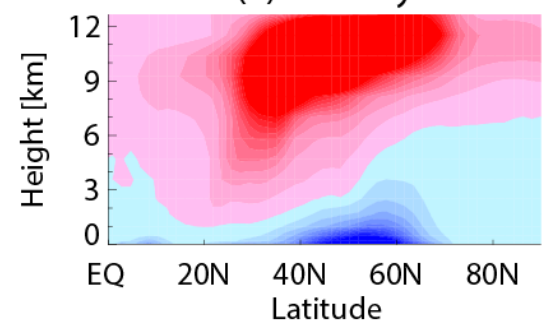

(b) July

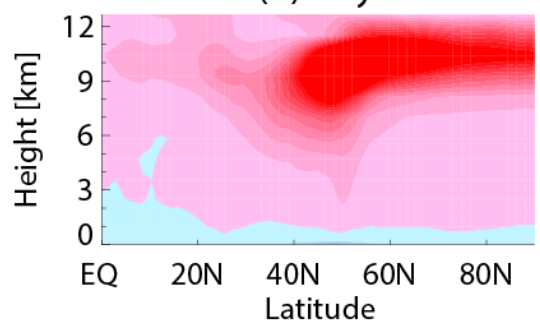

\begin{tabular}{cccc}
\hline$-2.0 \mathrm{E}-11$ & $\begin{array}{c}-1.0 \mathrm{E}-11 \\
\text { NOx volume mixing ratio difference }\end{array}$ & $\begin{array}{l}1.0 \mathrm{E}-11 \\
\end{array}$ \\
& & $2.0 \mathrm{E}-11$
\end{tabular}

Percentage difference

(c) January

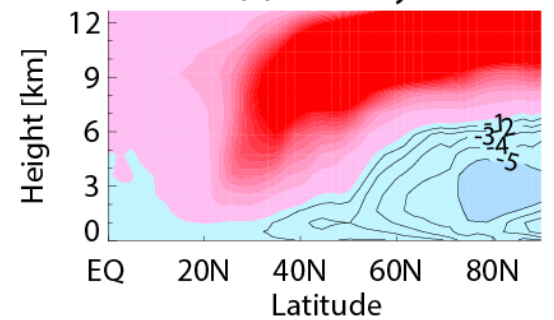

(d) July

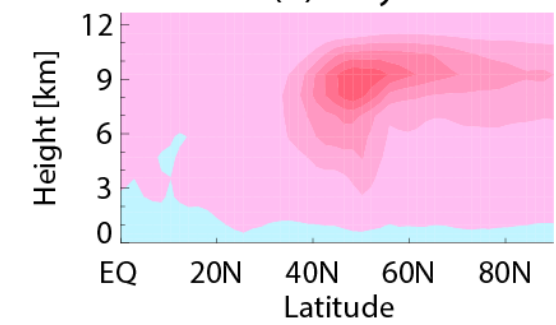
$-50$
$-25$
0
relative NOx difference [\%]
25
50

Fig. 5. Latitude-altitude distribution of differences in NOx between the control and the simulation with non-LTO aircraft emissions averaged over longitude $0^{\circ} \mathrm{E}$ and $90^{\circ} \mathrm{E}$ in ( a and a) January (left column) and (b and d) July (right column). (a) and (b) are the volume mixing ratio differences, (nonLTO-CTRL), and (c) and (d) are percentage differences to the background $\mathrm{NO}_{\mathrm{x}}$ concentration, (nonLTO-CTRL)/(CTRL) $\times 100 \%$.

important than in winter. CAM-chem includes the following reactions.

$\mathrm{N}_{2} \mathrm{O}_{5} \rightarrow 2 \mathrm{HNO}_{3}$

$\mathrm{NO}_{3} \rightarrow \mathrm{HNO}_{3}$

$\mathrm{NO}_{2} \rightarrow 0.5 \times\left(\mathrm{OH}+\mathrm{NO}+\mathrm{HNO}_{3}\right)$

Under high aerosol concentrations, the heterogeneous reactions listed above can effectively remove $\mathrm{NO}_{3}$ and $\mathrm{N}_{2} \mathrm{O}_{5}$ from the atmosphere even under low $\mathrm{OH}$ concentrations and low humidity. Therefore, this set of heterogeneous reactions can be a key to explain the greater surface perturbations in January. With low background aerosol concentrations in the middle troposphere, non-LTO emissions maintain larger $\mathrm{NO}_{\mathrm{x}}$ perturbations (Fig. 5) in Europe by limiting the heterogeneous formation of $\mathrm{HNO}_{3}$ more in January compared to July. Aviation emissions are sources of $\mathrm{PM}_{2.5}$, but the $\mathrm{PM}_{2.5}$ perturbation due to aviation emissions is three orders of magnitude smaller than the background level of $\mathrm{PM}_{2.5}$ both in January and July (see later in Fig. 9). So the effects of nonLTO emissions on the boundary layer $\mathrm{NO}_{\mathrm{x}}$ and $\mathrm{O}_{3}$ strongly depend on the seasonal variation of background aerosols.
To further examine the downward propagation of $\mathrm{NO}_{\mathrm{x}}$ and $\mathrm{O}_{3}$ perturbations, we carried out two additional simulations. We added cruise altitude emissions to the model run "CTRL" as forcing for 30 days from the beginning of January and the beginning of July. Figures 6 and 7 show the downward propagation of $\mathrm{NO}_{\mathrm{x}}$ and $\mathrm{O}_{3}$ perturbations from cruise altitudes down to the planetary boundary layer. The analyses are zonally averaged between $0^{\circ} \mathrm{E}$ and $90^{\circ} \mathrm{E}$. In Fig. 6, the signals in $\mathrm{NO}_{\mathrm{x}}$ changes are noticeable only at cruise altitudes showing higher than 10 pptv of increase. So the $\mathrm{NO}_{\mathrm{x}}$ perturbation in low troposphere shown in Fig. 5 is not due to vertical transport, also found in the analyses by Whitt et al. (2011). Figure 7 shows that the $\mathrm{O}_{3}$ perturbation also weakens with decreased altitude. However, compared to its peak perturbation at the mid-latitudes cruise altitude, $\mathrm{O}_{3}$ perturbation does not weaken as much as $\mathrm{NO}_{\mathrm{x}}$. When $\mathrm{O}_{3}$ is increased by $\mathrm{NO}_{\mathrm{x}}$ emissions, small portion of the $\mathrm{O}_{3}$ perturbation is transported down to the surface. In the boundary layer, $\mathrm{O}_{3}$ perturbation is between $0.1-0.5 \mathrm{ppbv}$ after Day 20. This $\mathrm{O}_{3}$ perturbation can also result in the small $\mathrm{NO}_{\mathrm{x}}$ or $\mathrm{NO}_{\mathrm{y}}$ perturbation in the boundary layer by changing the $\mathrm{NO}-\mathrm{NO}_{2}-\mathrm{O}_{3}$ photostationary state. Seasonally, due to the difference in background 
(a) January

Day 5

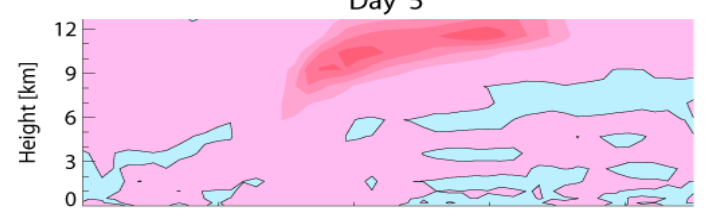

Day 10

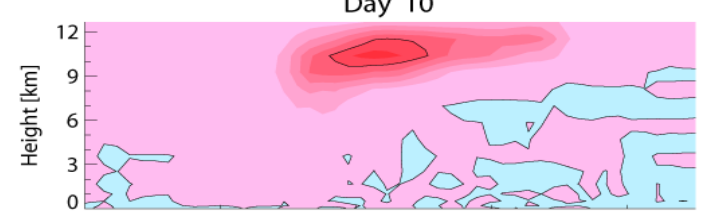

Day 15

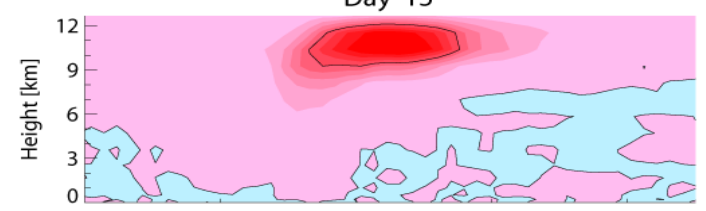

Day 20

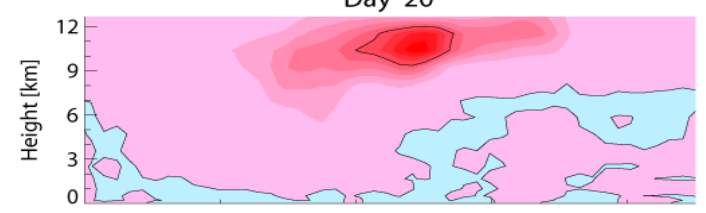

Day 25

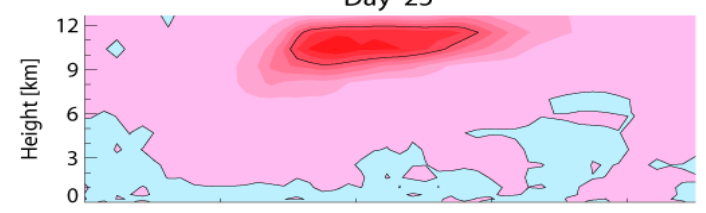

Day 30

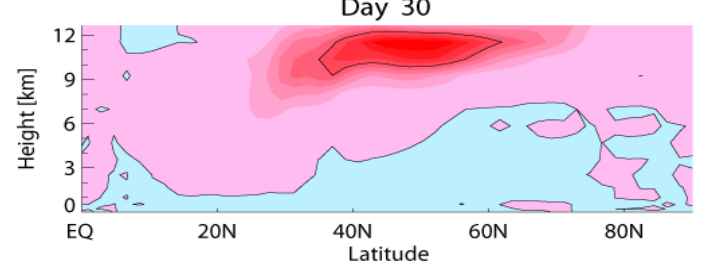

(b) July

Day 5

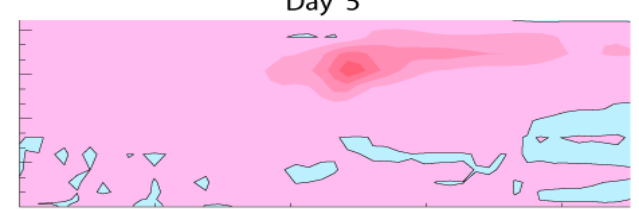

Day 10

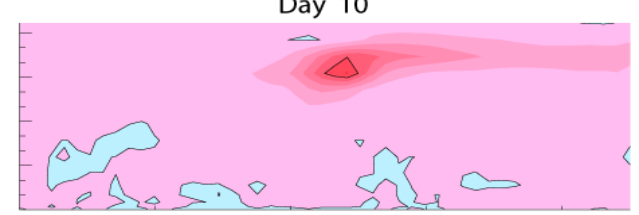

Day 15

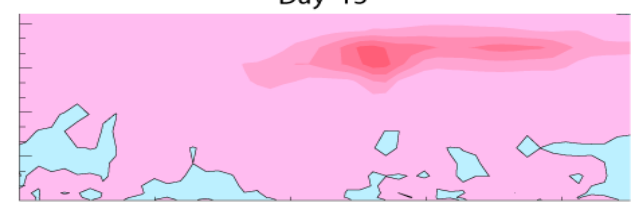

Day 20

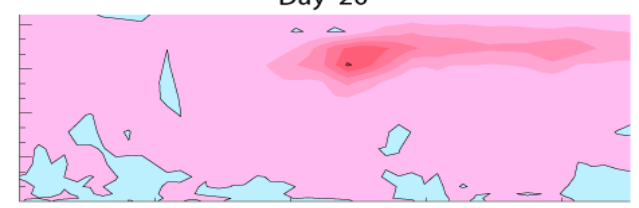

Day 25

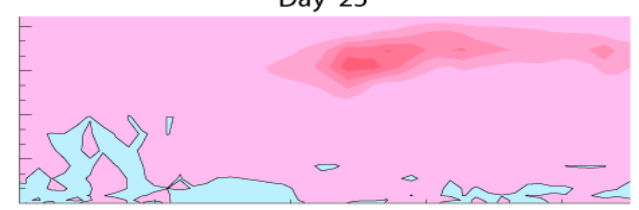

Day 30

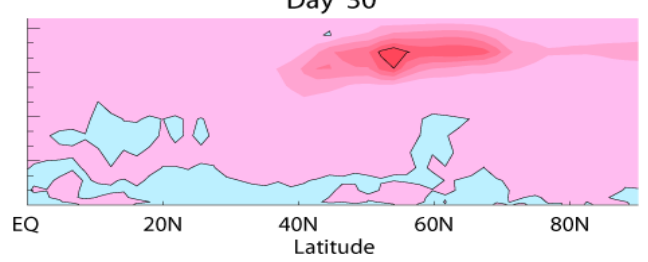

1.0E-11

4.0E-11

7.0E-11

Fig. 6. Propagation of $\mathrm{NO}_{\mathrm{x}}$ perturbation resulted from suddenly imposed cruise level emissions for 30 days on CTRL outputs at the beginning of (a) January and (b) July. Perturbations are zonally averaged between longitude $0^{\circ} \mathrm{E}$ and $90^{\circ} \mathrm{E}$. Solid lines indicate where the perturbations are $0.05 \mathrm{ppbv}$.

aerosols, the perturbations of $\mathrm{O}_{3}$ are slightly greater in the lower troposphere in January than in July. However, the $\mathrm{O}_{3}$ enhancement of about 0.1 ppbv in January does not have a substantial effect on air quality.

\subsection{Changes in aerosols}

Figure 8 shows the effects of aircraft emissions on $\mathrm{PM}_{2.5}$ in the boundary layer. Only statistically significant signals with confidence levels higher than $95 \%$ according to the student t-test for paired samples are color shaded. The perturbation of $\mathrm{PM}_{2.5}$ in July is less than $0.2 \%$ of the background $\mathrm{PM}_{2.5}$ 
(a) January
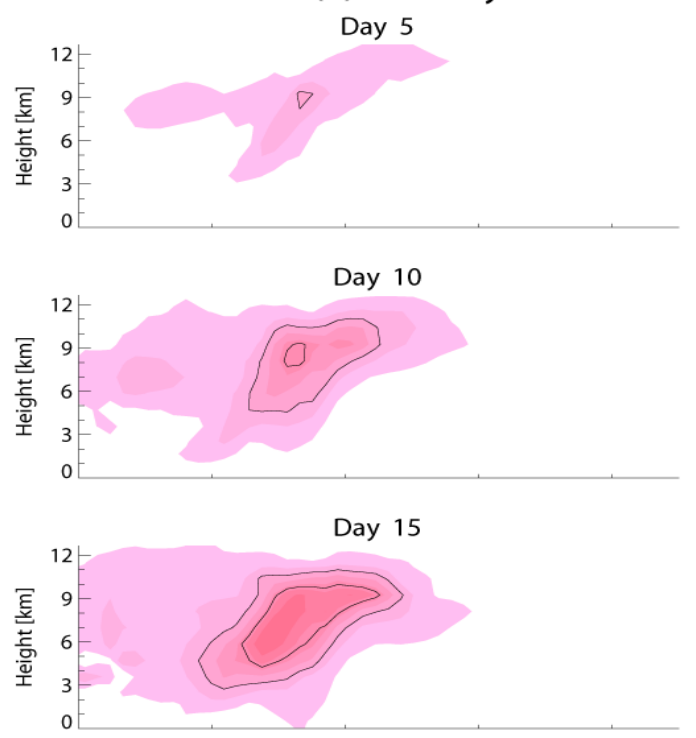

Day 20

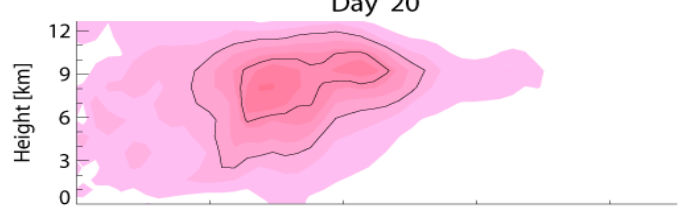

Day 25

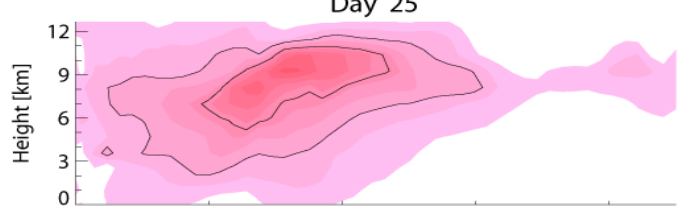

Day 30

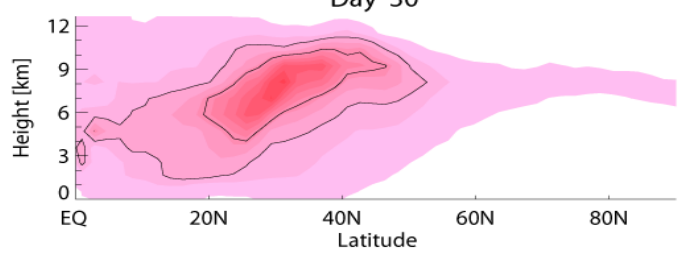

(b) July

Day 5

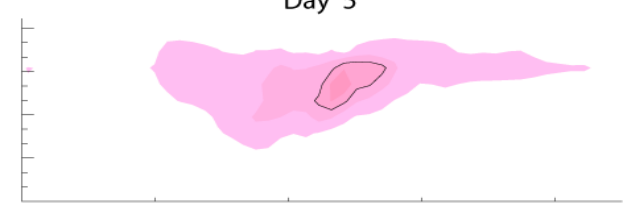

Day 10
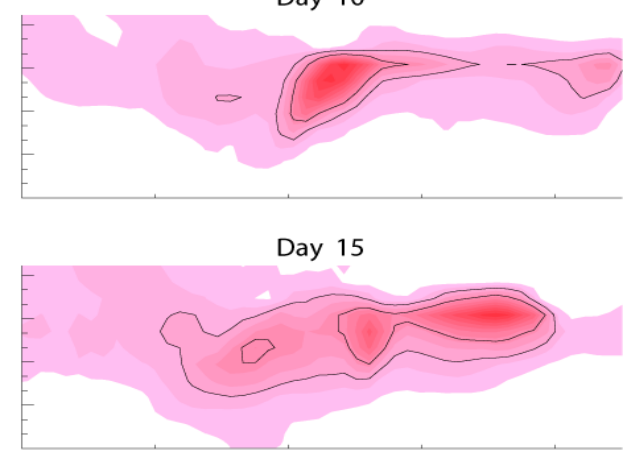

Day 20

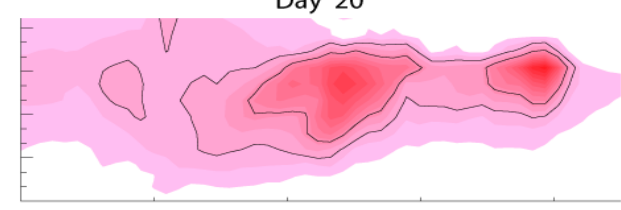

Day 25

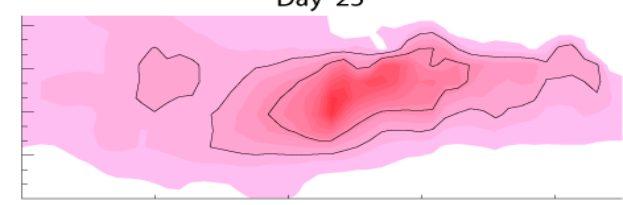

Day 30

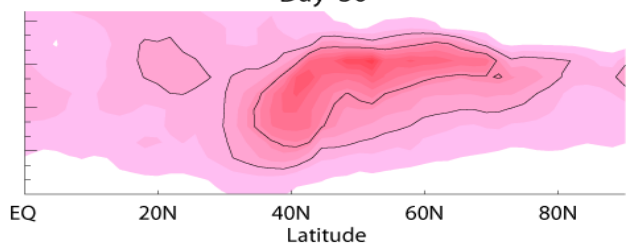

1.9E-09

3.1E-09

$\mathrm{O}_{3}$ volume mixing ratio difference

Fig. 7. Propagation of $\mathrm{O}_{3}$ perturbation resulted from suddenly imposed cruise level emissions for 30 days on CTRL outputs at the beginning of (a) January and (b) July. Only the perturbations larger than 0.1 ppbv are shaded. Perturbations are zonally averaged between longitude $0^{\circ} \mathrm{E}$ and $90^{\circ} \mathrm{E}$. Solid lines indicate where the perturbations are 0.5 and $1 \mathrm{ppbv}$.

and quite limited near the subtropical Atlantic Ocean and the US west coast (not shown). On the other hand, in January, $\mathrm{PM}_{2.5}$ increases by about $0.1 \mathrm{ppb}$ (roughly $0.1 \mu \mathrm{g} \mathrm{m}^{-3}$ ) in the Midwest and East Coast of the US, in Europe, and in East Asia. This increase is smaller than that shown in Barrett et al. (2010), despite the similarity in the spatial distributions of $\mathrm{PM}_{2.5}$ perturbations. The larger $\mathrm{NO}_{\mathrm{x}}$ emissions used in
Barrett et al. (2010) for the low and nominal cases may be responsible for the difference. By comparing effects of the total (Fig. 8a) and non-LTO emissions (Fig. 8b) on $\mathrm{PM}_{2.5}$, it is obvious that the change in $\mathrm{PM}_{2.5}$ is mainly from non-LTO emissions similar to Barrett et al. (2010). LTO emissions in Fig. 8c are not important in terms of aerosol loading in the planetary boundary layer both in summer and winter. 


\section{(a) total aircraft emissions}

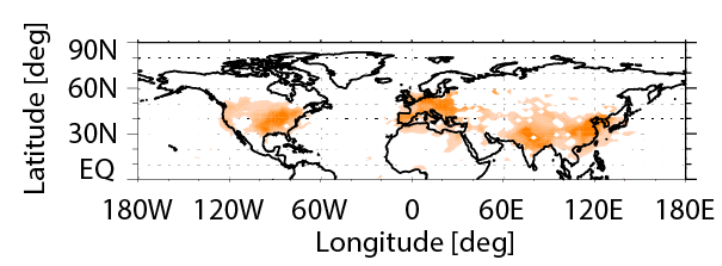

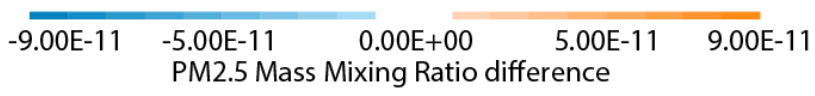

(b) non-LTO emissions ( $z>1 \mathrm{~km}$ )

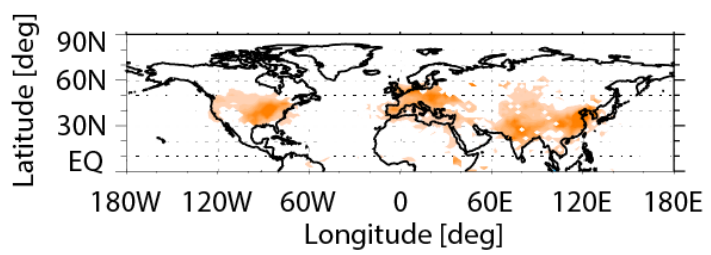

(c) LTO emissions ( $z<=1 \mathrm{~km}$ )

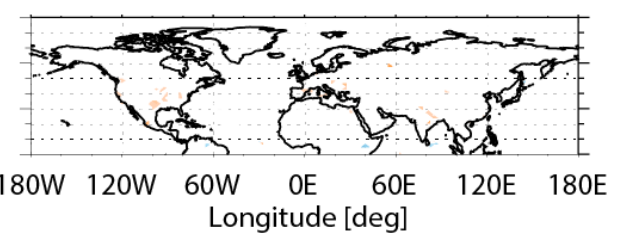

Fig. 8. Differences in the boundary layer $\mathrm{PM}_{2.5}$ between the control and the simulations with aircraft emissions in January. (a) [ALL-CTRL], (b) [nonLTO-CTRL] and (c) [ALL-nonLTO].

(a) January

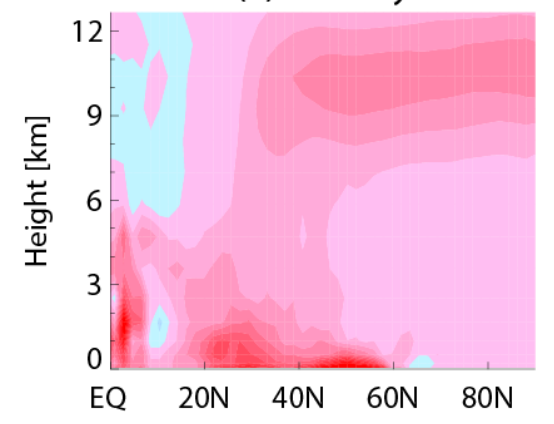

(b) July

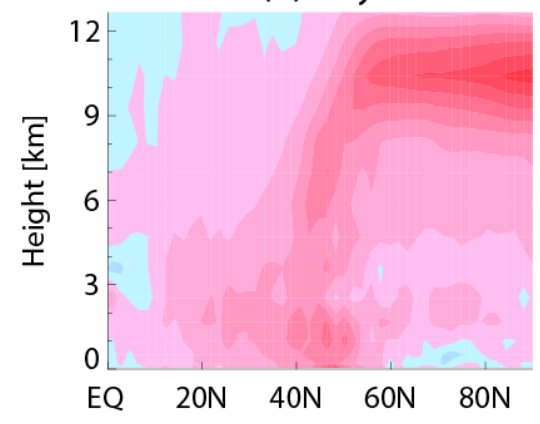

\begin{tabular}{llcccc}
\hline$-3.0 \mathrm{E}-11$ & $-1.8 \mathrm{E}-11$ & $-6.0 \mathrm{E}-12$ & $6.0 \mathrm{E}-12$ & $1.8 \mathrm{E}-11$ & $3.0 \mathrm{E}-11$ \\
& & &
\end{tabular}

Fig. 9. Latitude-altitude distribution of differences in mass mixing ratio of $\mathrm{PM}_{2.5}$ between CTRL and non-LTO simulations averaged over longitude between $0^{\circ} \mathrm{E}$ and $90^{\circ} \mathrm{E}$ in (a) January and (b) July.

For a more detailed demonstration, we analyzed the $\mathrm{PM}_{2.5}$ perturbations zonally averaged between $0^{\circ} \mathrm{E}$ and $90^{\circ} \mathrm{E}$ (Fig. 9). Near the cruise altitudes, $\mathrm{PM}_{2.5}$ perturbations are greater in July than in January, whereas the boundary layer $\mathrm{PM}_{2.5}$ increases much more in January than in July. Figure 10 shows that the overall $\mathrm{PM}_{2.5}$ increases in January are mostly due to the increased $\mathrm{NH}_{4} \mathrm{NO}_{3}$. This result is consistent with Fig. 3 of Barrett et al. (2010). In the wintertime boundary layer, the increased $\mathrm{HNO}_{3}$ that has a longer lifetime than
$\mathrm{NO}_{\mathrm{x}}$ determines the effects of the non-LTO emissions on the boundary layer $\mathrm{PM}_{2.5}$, rather than directly emitted aerosols from aircraft. Therefore, it is the amount of $\mathrm{NO}_{\mathrm{x}}$ emissions from aircraft that determine the $\mathrm{PM}_{2.5}$ perturbation at the ground.

In January, the sulfate production is strong near the cruise altitudes, decreases as altitude decreases and becomes almost zero near the ground. In contrast, for July, the sulfate aerosols dominate the $\mathrm{PM}_{2.5}$ perturbation. However, the student t-test 
(a) January
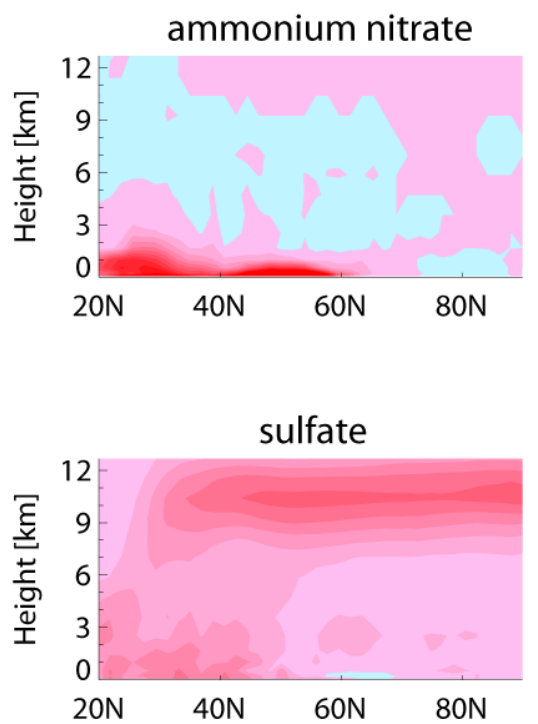

(b) July
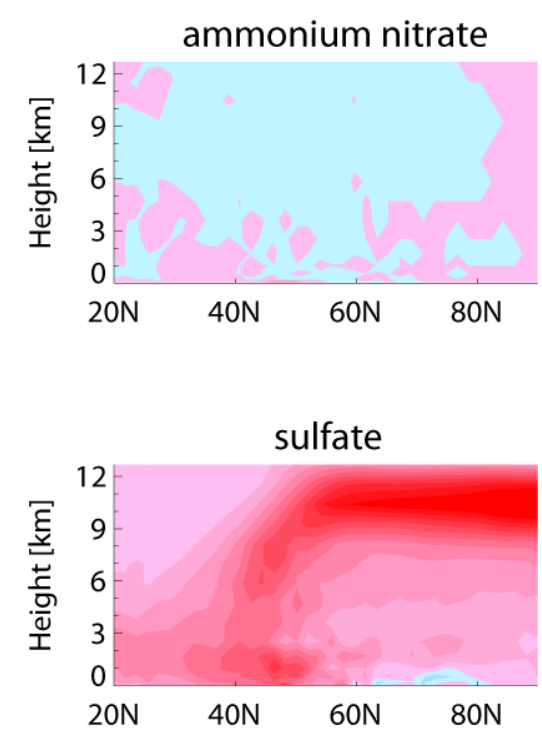

\begin{tabular}{lllll}
\hline$-5.0 \mathrm{E}-12$ & $-2.5 \mathrm{E}-12$ & $0.0 \mathrm{E}+00$ & $2.5 \mathrm{E}-12$ & $5.0 \mathrm{E}-12$ \\
& \multicolumn{2}{c}{ mass mixing ratio difference } & &
\end{tabular}

Fig. 10. Latitude-altitude distribution of differences in [top] ammonium nitrate and [bottom] sulfate between the control and non-LTO simulation. The differences were averaged over longitude $0^{\circ} \mathrm{E}$ and $90^{\circ} \mathrm{E}$ in (a) January (let column) and (b) July (right column).

shows that the resulting $\mathrm{PM}_{2.5}$ perturbation, including the sum of ammonium nitrate and sulfate resulting from aviation emissions, is not statistically significant at the ground level. The perturbations of $\mathrm{BC}$ and OC due to non-LTO emissions are much smaller than $\mathrm{NH}_{4} \mathrm{NO}_{3}$ in affecting $\mathrm{PM}_{2.5}$ in agreement with Barrett et al. (2010). Therefore, using different emission indices for $\mathrm{SO}_{2}$ or $\mathrm{BC}$ do not affect our results, nor does the hydrophilic assumption for BC and OC.

The question remains: is this small change in $\mathrm{PM}_{2.5}$, mostly in $\mathrm{NH}_{4} \mathrm{NO}_{3}$ in winter, really statistically significant? Also does the change significantly increase mortality as claimed in Barrett et al. (2010) or not? In regions with heavy air traffic, such as the US and Europe, non-LTO emissions increase $\mathrm{PM}_{2.5}$ by about $0.5 \%$. Although the perturbations at some grid points are statistically significant based on the student's t-test, it is hard to say that these aerosol changes that are smaller than $0.2 \mu \mathrm{g} \mathrm{m}^{-3}$ and represent $1 \%$ of the background $\mathrm{PM}_{2.5}$ are meaningful considering the uncertainty of $\mathrm{PM}_{2.5}$ in state-of-the-art models (e.g., uncertainty of $\mathrm{PM}_{2.5}$ in CMAQ model is $5 \mu \mathrm{g} \mathrm{m}^{-3}$ in Hogrefe et al., 2007).

Analyses of mortality due to $\mathrm{PM}_{2.5}$ in the previous studies have used different PM2.5 concentration-response functions, but commonly considered only large changes in PM concentrations. For example, Schwartz et al. (2002) found that $10 \mu \mathrm{g} \mathrm{m}^{-3}$ and $20 \mu \mathrm{g} \mathrm{m}^{-3}$ of $\mathrm{PM}_{2.5}$ concentration difference is associated with $1.5 \%$ death increase. However, in Schwartz et al. (2002), the death increase is not significant for background $\mathrm{PM}_{2.5}$ concentrations lower than $15 \mu \mathrm{g} \mathrm{m} \mathrm{m}^{-3}$. Thus, it is not clear how these impacts may be applied to interpret the extremely small PM2.5 perturbations of at most $0.1 \mu \mathrm{g} \mathrm{m}^{-3}$, as shown in Fig. 8. Additionally, a recent study, Huang et al. (2012), found that an increase of $10 \mu \mathrm{g} \mathrm{m}^{-3}$ for $\mathrm{PM}_{2.5}$ resulted in an increased risk of mortality of about $0.2 \%$ (in Xian, China where the annual average concentration of $\mathrm{PM}_{2.5}$ is about $176.7 \mu \mathrm{g} \mathrm{m}^{-3}$ ). This value is $\sim 7$ times lower than the $1.5 \%$ reported in Schwartz et al. (2002). Therefore, we currently concluded The overall impact of aviation emissions on surface $\mathrm{PM}_{2.5}$ is extremely small so that mortality cannot be determined from small signal with any certainty.

Another important uncertainty to consider is the background concentration of $\mathrm{NH}_{3}$. Despite the importance of $\mathrm{NH}_{3}$ in evaluating air quality, aerosol formation and acid deposition, there are relatively few reliable observations of $\mathrm{NH}_{3}$. In addition, most of the available observations were locally made and cover only the boundary layer (e.g., Nowak et al., 2007 and 2010). The retrieved $\mathrm{NH}_{3}$ distribution in Clarisse et al. (2009) is the only reliable global map of column $\mathrm{NH}_{3}$, which is based on the Infrared Atmospheric Sounding Interferometer (IASI) onboard the tropospheric emission spectrometer (TES). We, thus, compared the $\mathrm{NH}_{3}$ column concentration from our simulations with that in Clarisse et al. (2009) and conducted a sensitivity study to demonstrate the role of $\mathrm{NH}_{3}$ in the aviation effects on air 


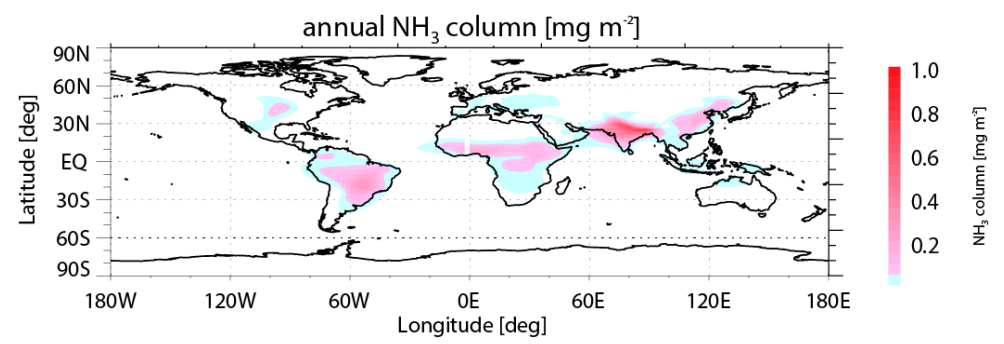

Fig. 11. Annual averaged $\mathrm{NH}_{3}$ columns in the control simulation.

(a) PM 2.5 difference

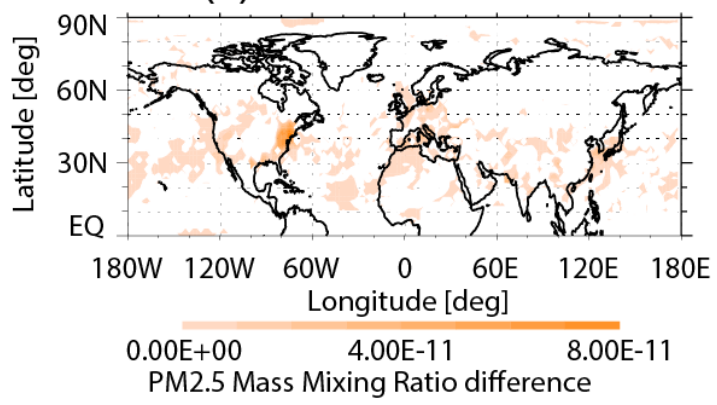

(b) relative difference

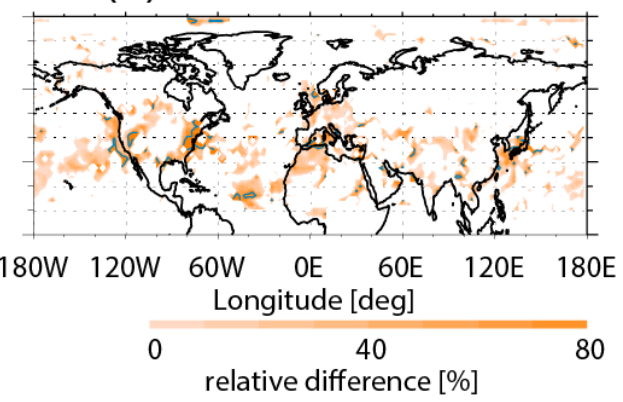

Fig. 12. (a) Differences in the boundary layer $\mathrm{PM}_{2.5}$ due to the doubled $\mathrm{NH}_{3}$ flux $\left(\mathrm{ALL}_{2} \times \mathrm{NH}_{3}-\mathrm{CTRL} \mathrm{L}_{2} \times \mathrm{NH}_{3}-\mathrm{ALL}+\mathrm{CTRL}\right)$ in $\mathrm{January}_{\text {. }}$ (b) The relative $\mathrm{PM}_{2.5}$ perturbation $\left(\mathrm{ALL}_{2} \times \mathrm{NH}_{3}-\mathrm{CTRL}_{2} \times \mathrm{NH}_{3}\right) /(\mathrm{ALL}-\mathrm{CTRL}) \times 100$ [\%].The green contours indicate regions of higher than $100 \%$ of $\mathrm{PM}_{2.5}$ differences. The green contours indicate regions of higher than $100 \%$ of $\mathrm{PM}_{2.5}$ differences.

quality. The formation of sulfate aerosols is preferred over $\mathrm{NH}_{4} \mathrm{NO}_{3}$ (Seinfeld and Pandis, 2006) in CAM-chem. In an ammonia-poor atmosphere, all of the free ammonia is used to produce sulfate aerosols.

In Fig. 11, the annual average total column $\mathrm{NH}_{3}$ used in our simulations is plotted. Compared to the observed $\mathrm{NH}_{3}$ distribution in Clarisse et al. (2009), there is overall good qualitative agreement in the spatial distribution of $\mathrm{NH}_{3}$ between CAM-chem and IASI. However, some differences are found in multiple regions. The $\mathrm{NH}_{3}$ in CAM-chem is not as high as IASI on the West Coast of the US and Central Asia. The peaks of IASI $\mathrm{NH}_{3}$ in Southern China and South America are not displayed as clearly as in Fig. 11. Therefore, it should be kept in mind that substantial uncertainties remain in the background $\mathrm{NH}_{3}$ concentration included in CAM-chem.

To determine whether more abundant $\mathrm{NH}_{3}$ makes a significant difference in the aviation impacts on $\mathrm{PM}_{2.5}$, the additional enhancement of $\mathrm{PM}_{2.5}$ due to doubled $\mathrm{NH}_{3}$ flux is plotted in Fig. 12. The mixing ratio differences of $\mathrm{PM}_{2.5}$ in January (ALL_ $2 \times \mathrm{NH}_{3}-\mathrm{CTRL} \_2 \times \mathrm{NH}_{3}-\mathrm{ALL}+\mathrm{CTRL}$ in Table 2) on the left panel were divided by the $\mathrm{PM}_{2.5}$ perturbation in Fig. 8a and plotted on the right panel (Fig. 12b). As shown earlier, the non-LTO emissions explain a large portion of the changes in $\mathrm{PM}_{2.5}$; Fig. 12 can be interpreted as the impacts of non-LTO emissions affected by higher background $\mathrm{NH}_{3}$. With doubled $\mathrm{NH}_{3}$, the enhancement of $\mathrm{PM}_{2.5}$ be- comes substantially larger on the East Coast of the US. In this region with heavy air traffic, doubled ground $\mathrm{NH}_{3}$ fluxes increase the $\mathrm{PM}_{2.5}$ perturbation by more than $100 \%$ relative to the perturbation with reference background $\mathrm{NH}_{3}$ (Fig. 12b). This sensitivity study suggests that one must carefully consider the large uncertainties in background $\mathrm{NH}_{3}$ when evaluating the aviation effects on surface aerosols. Currently there is no global $\mathrm{NH}_{3}$ observational dataset to validate model simulated background $\mathrm{NH}_{3}$. Given the imperfect $\mathrm{NH}_{3}$ database and other uncertainties, such as the assumed emission indices for aerosols from aircraft, there remain substantial questions regarding the meaning of the statistically significant signals for the small changes of simulated $\mathrm{NO}_{\mathrm{x}}, \mathrm{O}_{3}$ and $\mathrm{NH}_{4} \mathrm{NO}_{3}$ due to non-LTO emissions.

Until now, we used the student's t-test for paired samples (as in Barrett et al., 2010) to determine statistical significance of the monthly averaged perturbations at each grid point of model outputs. Because the student's t-test only evaluates significance of the difference between two mean values, statistical significance from the t-test does not have any implications in the frequency of extreme high values of $\mathrm{PM}_{2.5}$ that are our major concern regarding public health. Therefore, a more appropriate statistical tool to test the difference in PDFs for a certain region of our interest is applied to determine significance of aviation emission impacts on occurrence of extreme events. In Fig. 13, the PDFs of daily $\mathrm{PM}_{2.5}$ over Europe $\left(15^{\circ} \mathrm{W}-45^{\circ} \mathrm{E}, 35-65^{\circ} \mathrm{N}\right)$ and the entire Northern 
(a) Europe

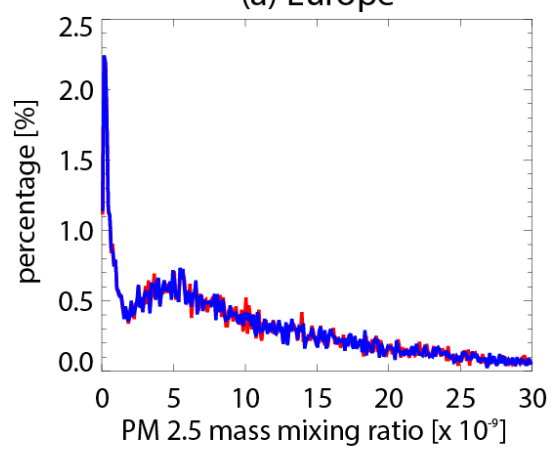

(c) Europe

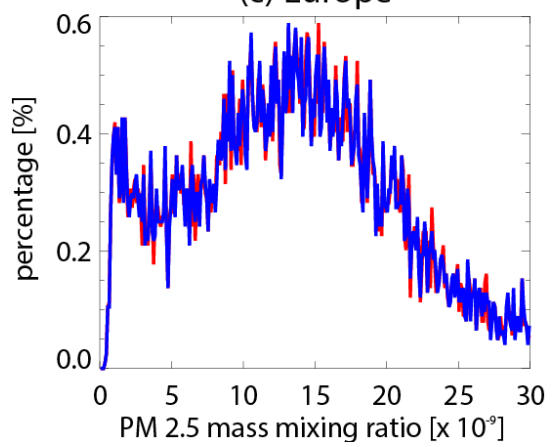

January

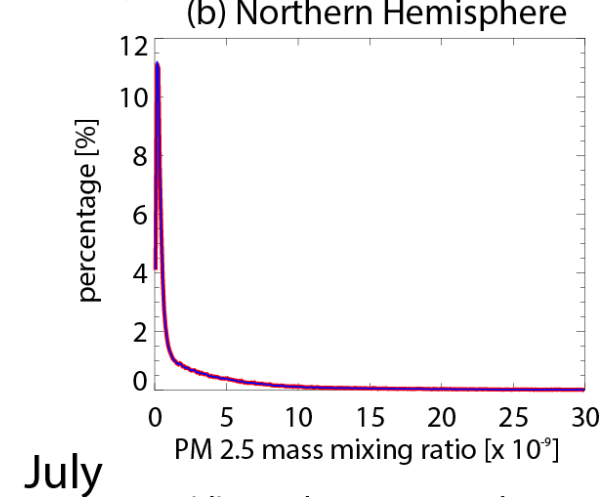

(d) Northern Hemisphere

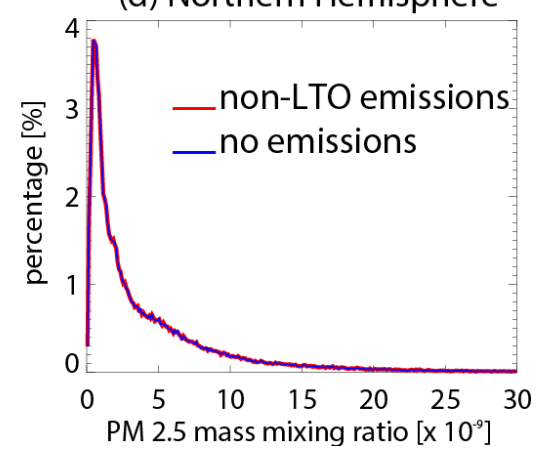

Fig. 13. Probability density functions (PDFs) of the ground $\mathrm{PM}_{2.5}$ for (a and c) Europe $\left(15^{\circ} \mathrm{W}-45^{\circ} \mathrm{E}\right)$ and (b and d) the entire Northern Hemisphere in January [top] and July [bottom]. Red and blue lines represent PDFs from runs with non-LTO emissions and no aircraft emissions, respectively.

Table 3. Empirical p-values for the Hellinger distance to test similarity of $\mathrm{PM}_{2.5}$ PDF with non-LTO emissions and PDF without aircraft emissions as shown in Fig. 13. [Unit is \%]. Higher p-values (close to 100) mean better agreement of two PDFs.

\begin{tabular}{lrrrrrrrrrrrr}
\hline & \multicolumn{10}{c}{ Month } \\
\cline { 2 - 13 } & 1 & 2 & 3 & 4 & 5 & 6 & 7 & 8 & 9 & 10 & 11 & 12 \\
\hline Europe & 99 & 99.5 & 100 & 100 & 100 & 100 & 100 & 100 & 100 & 100 & 97.5 & 87 \\
NH & 100 & 100 & 100 & 100 & 100 & 100 & 100 & 100 & 100 & 100 & 100 & 100 \\
\hline
\end{tabular}

Hemisphere were compared between two simulations with non-LTO emissions (red) and without any aviation emissions (blue). Qualitatively, the two PDFs in each panel of Fig. 13 are nearly identical.

For a quantitative comparison between PDFs, the Hellinger distance (Tilmes et al., 2012; Lee et al., 2012) was calculated. The Hellinger distance between two probability density functions of a random variable $\mathrm{x}, \mathrm{f}(\mathrm{x})$ and $\mathrm{g}(\mathrm{x})$, is defined as

$H=\left[\frac{1}{2} \int(\sqrt{f(x)}-\sqrt{g(x)})^{2} d x\right]^{0.5}$

When the two PDFs $(f(x)$ and $g(x)$ are identical, $\mathrm{H}$ is 0 . For two PDFs with no overlap, $\mathrm{H}$ becomes 1 . The smaller $\mathrm{H}$ values, the more similar two PDFs are. However, since $\mathrm{H}$ values depend on the interval of the PDF bins, $\mathrm{H}$ alone is not a robust statistic to test the difference between PDFs. Therefore, we calculated p-values to quantitatively test the null hypothesis, $\mathrm{H}_{0}$ : two PDFs are from the same population, using a bootstrap method (Faraway, 2005) with 1000 times of resampling. The $p$ value is the probability that the calculated $\mathrm{H}$ value occurs under the null hypothesis. When the $p$ value is smaller than $5 \%$, the two PDFs are different at confidence level of $95 \%$. When $p$ value is larger than $10 \%$, differences between two PDFs are not statistically significant. Table 3 lists related p-values for similarity between two PDFs in every month of the year. With a high confidence level, the four blue and red pairs of PDFs in Fig. 13 are identical to each other. Thus, aviation emissions do not cause statistically significantly changes in the distribution of surface $\mathrm{PM}_{2.5}$ in either January or July. 
Table 4. Frequency of higher daily averaged $\mathrm{PM}_{2.5}$ than $10-50 \mathrm{ppbm}$ in two simulations with and without FAA/AEDT aviation emissions. The numbers are from daily data over Europe $\left(15^{\circ} \mathrm{W}-45^{\circ} \mathrm{E}, 35-65^{\circ} \mathrm{N}\right)$, contiguous US $\left(120-60^{\circ} \mathrm{W}, 30-50^{\circ} \mathrm{N}\right)$ and East Asia $\left(100-150^{\circ} \mathrm{E}\right.$, $20-45^{\circ} \mathrm{N}$ ) in January.

\begin{tabular}{|c|c|c|c|c|c|c|}
\hline \multirow{2}{*}{$\begin{array}{l}\mathrm{PM}_{2.5}[\mathrm{ppbm}] \text { (approximate } \\
\text { concentration in } \mu \mathrm{g} \mathrm{m}^{-3} \text { ) }\end{array}$} & \multicolumn{2}{|c|}{ Europe (400 grid points $\times 31$ days) } & \multicolumn{2}{|c|}{ East Asia (294 grid points $\times 31$ days) } & \multicolumn{2}{|c|}{ US (300 grid points $\times 31$ days) } \\
\hline & $\begin{array}{l}\text { with FAA/AEDT } \\
\text { emissions }\end{array}$ & $\begin{array}{l}\text { without aviation } \\
\text { emissions }\end{array}$ & $\begin{array}{l}\text { with FAA/AEDT } \\
\text { emissions }\end{array}$ & $\begin{array}{l}\text { without aviation } \\
\text { emissions }\end{array}$ & $\begin{array}{l}\text { with FAA/AEDT } \\
\text { emissions }\end{array}$ & $\begin{array}{l}\text { without aviation } \\
\text { emissions }\end{array}$ \\
\hline $\begin{array}{l}>10 \\
(12)\end{array}$ & 5665 & 5660 & 3869 & 3858 & 2362 & 2350 \\
\hline $\begin{array}{l}>20 \\
(24)\end{array}$ & 3215 & 3209 & 1516 & 1513 & 409 & 406 \\
\hline $\begin{array}{l}>30 \\
(36)\end{array}$ & 1730 & 1729 & 467 & 464 & 5 & 5 \\
\hline $\begin{array}{l}>40 \\
(48)\end{array}$ & 788 & 786 & 140 & 138 & 0 & 0 \\
\hline $\begin{array}{l}>50 \\
(60)\end{array}$ & 319 & 320 & 43 & 39 & 0 & 0 \\
\hline
\end{tabular}

We further examined aviation impacts on $\mathrm{PM}_{2.5}$ using the FAA/AEDT emissions dataset. Even with $30 \%$ larger $\mathrm{NO}_{\mathrm{x}}$ emissions, the $\mathrm{PM}_{2.5}$ perturbations in this simulation are only slightly larger than found with the 1999 emissions (not shown). Aviation emissions still do not make statistically significant changes to the PDF of $\mathrm{PM}_{2.5}$ in Europe $\left(15^{\circ} \mathrm{W}\right.$ $\left.45^{\circ} \mathrm{E}, 35-65^{\circ} \mathrm{N}\right)$, contiguous US $\left(120-60^{\circ} \mathrm{W}, 30-50^{\circ} \mathrm{N}\right)$ and East Asia $\left(100-150^{\circ} \mathrm{E}, 20-45^{\circ} \mathrm{N}\right)$. Table 4 compares the frequency of high $\mathrm{PM}_{2.5}$ occurrences over the three regions between the two runs with and without FAA/AEDT aviation emissions for January. Considering the total number of data used here ( 31 daily values from 400, 294 and 300 grid points covering Europe, East Asia and the US, respectively), it is clear that neither non-LTO nor LTO emissions result in more frequent $\mathrm{PM}_{2.5}$ concentrations higher than the EPA standard $\left(35 \mu \mathrm{g} \mathrm{m}^{-3}\right)$ for $24 \mathrm{~h}$ average.

\section{Conclusions}

In this study, the effects of aircraft emissions on boundary layer air quality have been examined by comparing and analyzing simulation results from the CAM-chem chemistrytransport model. The air quality impacts were evaluated from the differences of $\mathrm{O}_{3}, \mathrm{NO}_{\mathrm{y}}$ and $\mathrm{PM}_{2.5}$ concentrations between a baseline control simulation without aviation emissions and the simulations with the total or partial aircraft emissions. We separated effects of the total aviation emissions into LTO and non-LTO emissions and found that nonLTO emissions do have a small effect on $\mathrm{NO}_{\mathrm{y}}, \mathrm{O}_{3}$ and $\mathrm{PM}_{2.5}$ concentrations in the boundary layer. However, these effects are too small to meaningfully affect air quality.

The vertical propagation of perturbations due to non-LTO emissions is influenced by heterogeneous reactions occurring on aerosols. This highlights the importance of having accurate vertical distributions of background aerosol to assess the air quality impacts of non-LTO emissions. Additionally increased aerosols in the future could further weaken the ef- fects of non-LTO emissions on $\mathrm{NO}_{\mathrm{x}}$ and $\mathrm{O}_{3}$ in the boundary layer. The sensitivity of vertical propagation processes to background aerosol concentrations has the potential to become a useful tool to compare and evaluate different chemistry models to be used to simulate aviation impacts on air quality.

Non-LTO aircraft emissions cause an overall global increase in $\mathrm{O}_{3}$ both in January and July. However, the $\mathrm{O}_{3}$ perturbations are smaller in July so that the contribution of aviation emissions to summer time $\mathrm{O}_{3}$ near the ground can be negligible in terms of air pollution. In January, aircraft emissions lead to decreases in $\mathrm{NO}_{\mathrm{y}}$ by $1-2 \%$ in the US East Coast, Europe and East Asia, whereas $\mathrm{NO}_{\mathrm{y}}$ is slightly increased by aircraft emissions in July. Similar to $\mathrm{O}_{3}$, the signal of the $\mathrm{NO}_{\mathrm{y}}$ perturbation in July is smaller than in January. Heterogeneous reactions and $\mathrm{NO}_{3}$ radical are important in removing the $\mathrm{NO}_{\mathrm{x}}$ perturbation in winter. Because $\mathrm{NO}_{\mathrm{x}}$ is a major source of $\mathrm{O}_{3}$ in the troposphere, the negative $\mathrm{NO}_{\mathrm{x}}$ perturbation limits the $\mathrm{O}_{3}$ perturbation in winter.

Similar to Barrett et al. (2010), the secondary aerosol perturbations due to non-LTO aviation emissions were found to have statistically significant signals at some grid points in the US, Europe and East Asia. $\mathrm{HNO}_{3}$ increases due to aviation emissions lead to formation of $\mathrm{NH}_{4} \mathrm{NO}_{3}$ in the wintertime boundary layer. The low temperature and relatively large $\mathrm{NO}_{\mathrm{y}}$ perturbation in January provides a favorable condition to increase $\mathrm{NH}_{4} \mathrm{NO}_{3}$ aerosols. However, the $\mathrm{NH}_{4} \mathrm{NO}_{3}$ perturbations are too small to be meaningful relative to stateof-the-art models' uncertainty. In addition, considering the critical role of $\mathrm{NH}_{3}$ in the formation of $\mathrm{NH}_{4} \mathrm{NO}_{3}$, more detailed global observations of $\mathrm{NH}_{3}$ are needed for evaluation of models before one can make meaningful statements about the $\mathrm{PM}_{2.5}$ change resulting from aviation emissions.

Our quantitative comparison of the $\mathrm{PM}_{2.5}$ PDFs indicates that using either the Boeing 1999 or the FAA/AEDT 2006 aviation emissions do not make statistically significant changes in the overall simulated distributions of surface 
$\mathrm{PM}_{2.5}$ in Europe and throughout the entire Northern Hemisphere. Therefore, regardless of all the interesting findings, it is difficult to conclude that the changes in $\mathrm{O}_{3}$ and $\mathrm{PM}_{2.5}$ due to non-LTO emissions have any practical importance for surface air quality. Given the uncertainties and the small perturbations in $\mathrm{PM}_{2.5}$ due to aviation, we think it is premature to make any conclusions about mortality of aviation impacts with any certainty.

Acknowledgements. This project was supported by the Federal Aviation Administration, Aviation Climate Change Research Initiative (ACCRI) under Contract \#: 10-C-NE-UI amendment 001 with The Partnership for AiR Transportation Noise and Emissions Reduction (PARTNER). This work was done as a private venture and not in the author's capacity as an employee of the Jet Propulsion Laboratory, California Institute of Technology.

Edited by: P. Monks

\section{References}

Barrett, S. R. H., Britter, R. E., and Waitz, I. A.: Global Mortality Attributable to Aircraft Cruise Emissions, Environ. Sci. Technol., 44, 7736-7742, 2010.

Barth, M. C., Rasch, P. J., Kiehl, J. T., Benkovitz, C. M., and Schwartz, S. E.: Sulfur chemistry in the National Center for Atmospheric Research Community Climate Model: Description, evaluation, features, and sensitivity to aqueous chemistry, J. Geophys. Res.-Atmos., 105, 1387-1415, 2000.

Baughcum, S. L., Sutkus Jr., D. J., and Hendersonm, S. C.: Year 2015 Aircraft Emission Scenario for Scheduled Air Traffic, NASA-CR-1998-207638, 1998.

Brasseur, G. P., Müller, J. F., and Granier, C.: Atmospheric impact of NOx emissions by subsonic aircraft: A three-dimensional model study, J. Geophys. Res.-Atmos., 101, 1423-1428, 1996.

Brasseur, G. P., Cox, R. A., Hauglustaine, D., Isaksen, I., Lelieveld, J., Lister, D. H., Sausen, R., Schumann, U., Wahner, A., and Wiesen, P.: European scientific assessment of the atmospheric effects of aircraft emissions, Atmos. Environ., 32, 2329-2418, 1998.

Brasseur, G., Orlando, J. J., and Tyndall, G. S.: Atmospheric chemistry and global change, Oxford University Press, New York, Oxford, 1999.

Clarisse, L., Clerbaux, C., Dentener, F., Hurtmans, D., and Coheur, P. F.: Global ammonia distribution derived from infrared satellite observations, Nat. Geosci., 2, 479-483, 10.1038/ngeo551, 2009.

Cohen, A. J., Anderson, H. R., Ostro, B., Pandey, K. D., Krzyzanowski, M., Kunzli, N., Gutschmidt, K., Pope, A., Romieu, I., Samet, J. M., and Smith, K.: The global burden of disease due to outdoor air pollution, J. Toxicol. Env. Heal. A, 68, 1301-1307, doi:10.1080/15287390590936166, 2005.

Collins, W. J., Stevenson, D. S., Johnson, C. E., and Derwent, R. G.: Tropospheric ozone in a global-scale three-dimensional Lagrangian model and its response to NOX emission controls, J. Atmos. Chem., 26, 223-274, 1997.
Dameris, M., Grewe, V., Kohler, I., Sausen, R., Bruhl, C., Grooss, J. U., and Steil, B.: Impact of aircraft NOx emissions on tropospheric and stratospheric ozone. Part II: 3-D model results, Atmos. Environ., 32, 3185-3199, 1998.

EPA Report to congress on black carbon: http://www.epa.gov/ blackcarbon/2012report/fullreport.pdf, 2012.

Faraway, J. J.: Linear models with R, Chapman \& Hall/CRC, Boca Raton, FL, London, 2005.

FAA Aerospace Forecast: http://www.faa.gov/about/office_org/ headquarters_offices/apl/aviation_forecasts/aerospace_forecasts/ 2012-2032/media/2012\%20FAA\%20Aerospace\%20Forecast. pdf, 2012.

Heald, C. L., Jacob, D. J., Park, R. J., Russell, L. M., Huebert, B. J., Seinfeld, J. H., Liao, H., and Weber, R. J.: A large organic aerosol source in the free troposphere missing from current models, Geophys. Res. Lett., 32, L18809, doi:10.1029/2005gl023831, 2005.

Hendricks, J., Lippert, E., Petry, H., and Ebel, A.: Implications of subsonic aircraft NOx emissions for the chemistry of the lowermost stratosphere: Model studies on the role of bromine, J. Geophys. Res.-Atmos., 105, 6745-6759, 2000.

Herndon, S. C., Shorter, J. H., Zahniser, M. S., Nelson, D. D., Jayne, J., Brown, R. C., Miake-Lye, R. C., Waitz, I., Silva, P., Lanni, T., Demerjian, K., and Kolb, C. E.: NO and NO2 emission ratios measured from in-use commercial aircraft during taxi and takeoff, Environ. Sci. Technol., 38, 6078-6084, doi:10.1021/Es049701c, 2004.

Herndon, S. C., Jayne, J. T., Lobo, P., Onasch, T. B., Fleming, G., Hagen, D. E., Whitefield, P. D., and Miake-Lye, R. C.: Commercial aircraft engine emissions characterization of in-use aircraft at Hartsfield-Jackson Atlanta International Airport, Environ. Sci. Technol., 42, 1877-1883, doi:10.1021/Es072029, 2008.

Hogrefe, C., Hao, W., Civerolo, K., Ku, J. Y., Sistla, G., Gaza, R. S., Sedefian, L., Schere, K., Gilliland, A., and Mathur, R.: Daily simulation of ozone and fine particulates over New York State: findings and challenges, J. Appl. Meteorol. Clim., 46, 961-979, doi:10.1175/Jam2520.1, 2007.

Huang, W., Cao, J. J., Tao, Y. B., Dai, L. Z., Lu, S. E., Hou, B., Wang, Z., and Zhu, T.: Seasonal Variation of Chemical Species Associated With Short-Term Mortality Effects of $\mathrm{PM}_{2.5}$ in Xi' an, a Central City in China, Am. J. Epidemiol., 175, 556566, doi:10.1093/Aje/Kwr342, 2012.

Kohler, I., Sausen, R., and Reinberger, R.: Contributions of aircraft emissions to the atmospheric NOx content, Atmos Environ, 31, 1801-1818, 1997.

Lamarque, J. F., Kiehl, J. T., Hess, P. G., Collins, W. D., Emmons, L. K., Ginoux, P., Luo, C., and Tie, X. X.: Response of a coupled chemistry-climate model to changes in aerosol emissions: Global impact on the hydrological cycle and the tropospheric burdens of OH, ozone, and NOx, Geophys Res Lett, 32, doi:10.1029/2005GL023419, 2005.

Lamarque, J. F., Emmons, L. K., Hess, P. G., Kinnison, D. E., Tilmes, S., Vitt, F., Heald, C. L., Holland, E. A., Lauritzen, P. H., Neu, J., Orlando, J. J., Rasch, P. J., and Tyndall, G. K.: CAMchem: description and evaluation of interactive atmospheric chemistry in the Community Earth System Model, Geosci. Model Dev., 5, 369-411, 10.5194/gmd-5-369-2012, 2012.

Lee, D. S., Pitari, G., Grewe, V., Gierens, K., Penner, J. E., Petzold, A., Prather, M. J., Schumann, U., Bais, A., Berntsen, T., Iachetti, D., Lim, L. L., and Sausen, R.: Transport impacts on 
atmosphere and climate: Aviation, Atmos Environ, 44, 46784734, doi:10.1016/j.atmosenv.2009.06.005, 2010.

Lee, H., Youn, D., Patten, K. O., Olsen, S. C., and Wuebbles, D. J.: Diagnostic tools for evaluating quasihorizontal transport in global-scale chemistry models, J. Geophys. Res., 117, D19302, doi:10.1029/2012JD017644, 2012.

Lei, H., Wuebbles, D. J., and Liang, X. Z.: Projected risk of high ozone episodes in 2050, Atmos. Environ., 59, 567-577, 2012.

Lin, J. T., Youn, D., Liang, X. Z., and Wuebbles, D. J.: Global model simulation of summertime US ozone diurnal cycle and its sensitivity to PBL mixing, spatial resolution, and emissions, Atmos. Environ., 42, 8470-8483, doi:10.1016/j.atmosenv.2008.08.012, 2008.

Meijer, E. W., van Velthoven, P. F. J., Thompson, A. M., Pfister, L., Schlager, H., Schulte, P., and Kelder, H.: Model calculations of the impact of $\mathrm{NO}_{\mathrm{x}}$ from air traffic, lightning, and surface emissions, compared with measurements, J. Geophys. Res.-Atmos., 105, 3833-3850, 2000.

Morris, G. A., Rosenfield, J. E., Schoeberl, M. R., and Jackman, C. H.: Potential impact of subsonic and supersonic aircraft exhaust on water vapor in the lower stratosphere assessed via a trajectory model, J. Geophys. Res.-Atmos., 108, doi:10.1029/2002JD002614, 2003.

Nowak, J. B., Neuman, J. A., Kozai, K., Huey, L. G., Tanner, D. J., Holloway, J. S., Ryerson, T. B., Frost, G. J., McKeen, S. A., and Fehsenfeld, F. C.: A chemical ionization mass spectrometry technique for airborne measurements of ammonia, J Geophys Res-Atmos, 112, D10S02, doi:10.1029/2006JD007589, 2007.

Nowak, J. B., Neuman, J. A., Bahreini, R., Brock, C. A., Middlebrook, A. M., Wollny, A. G., Holloway, J. S., Peischl, J., Ryerson, T. B., and Fehsenfeld, F. C.: Airborne observations of ammonia and ammonium nitrate formation over Houston, Texas, J. Geophys. Res.-Atmos., 115, D22304, doi:10.1029/2010JD014195, 2010.

Olsen, S. C., Wuebbles, D. J., and Owen, B.: Comparison of global 3-D aviation emissions datasets, Atmos. Chem. Phys., 13, 429441, doi:10.5194/acp-13-429-2013, 2013.

Penner, J. E.: Aviation and the global atmosphere : a special report of IPCC Working Groups I and III in collaboration with the Scientific Assessment Panel to the Montreal Protocol on Substances that Deplete the Ozone Layer, Cambridge University Press, Cambridge, 1999.

Pison, I. and Menut, L.: Quantification of the impact of aircraft traffic emissions on tropospheric ozone over Paris area, Atmos. Environ., 38, 971-983, doi:10.1016/j.atmosenv.2003.10.056, 2004.

PM Standards Revision - 2006: http://www.epa.gov/oar/ particlepollution/naaqsrev2006.html, 2006.

Saiz-Lopez, A., Notario, A., Albaladejo, J., and McFiggans, G.: Seasonal variation of NOx loss processes coupled to the $\mathrm{HNO} 3$ formation in a daytime urban atmosphere: A model study, Water Air Soil Poll, 182, 197-206, doi:10.1007/s11270-006-9332-6, 2007.

Schumann, U., Schlager, H., Arnold, F., Ovarlez, J., Kelder, H., Hov, O., Hayman, G., Isaksen, I. S. A., Staehelin, J., and Whitefield, P. D.: Pollution from aircraft emissions in the North Atlantic flight corridor: Overview on the POLINAT projects, J. Geophys. Res.-Atmos., 105, 3605-3631, 2000.

Schurmann, G., Schafer, K., Jahn, C., Hoffmann, H., Bauerfeind, M., Fleuti, E., and Rappengluck, B.: The impact of NOx, CO and
VOC emissions on the air quality of Zurich airport, Atmos. Environ., 41, 103-118, doi:10.1016/j.atmosenv.2006.07.030, 2007.

Schurmann, G., Schafer, K., Jahn, C., Hoffmann, H., Bauerfeind, M., Fleuti, E., and Rappengluck, B.: The impact of NOx, CO and VOC emissions on the air quality of Zurich airport, Atmos Environ, 41, 103-118, doi:10.1016/j.atmosenv.2006.07.030, 2007.

Schwartz, J., Laden, F., and Zanobetti, A.: The concentrationresponse relation between $\mathrm{PM}_{2.5}$ and daily deaths, Environ. Health Persp., 110, 1025-1029, 2002.

Seinfeld, J. H. and Pandis, S. N.: Atmospheric chemistry and physics: from air pollution to climate change, 2nd ed. ed., Wiley, Hoboken, N. J., 2006.

Stevenson, D. S. and Derwent, R. G.: Does the location of aircraft nitrogen oxide emissions affect their climate impact?, Geophys Res Lett, 36, doi:10.1029/2009GL039422, 2009.

Stevenson, D. S., Collins, W. J., Johnson, C. E., and Derwent, R. G.: The impact of aircraft nitrogen oxide emissions on tropospheric ozone studied with a 3D Lagrangian model including fully diurnal chemistry, Atmos. Environ., 31, 1837-1850, 1997.

Sutkus Jr., D. J., Baughcum, S. L., and DuBois, D. P.: Scheduled Civil Aircract Emission Inventories for 1999: Database Development and Analysis, NASA-CR-2001-211216, 2001.

Tarrason, L. J. J. E., Berntsen, T. K., and Rypdal, K.: Study on air quality impacts of non-LTO emissions from aviation3, 2004.

Textor, C., Schulz, M., Guibert, S., Kinne, S., Balkanski, Y., Bauer, S., Berntsen, T., Berglen, T., Boucher, O., Chin, M., Dentener, F., Diehl, T., Easter, R., Feichter, H., Fillmore, D., Ghan, S., Ginoux, P., Gong, S., Grini, A., Hendricks, J., Horowitz, L., Huang, P., Isaksen, I., Iversen, I., Kloster, S., Koch, D., Kirkevåg, A., Kristjansson, J. E., Krol, M., Lauer, A., Lamarque, J. F., Liu, X., Montanaro, V., Myhre, G., Penner, J., Pitari, G., Reddy, S., Seland, Ø., Stier, P., Takemura, T., and Tie, X.: Analysis and quantification of the diversities of aerosol life cycles within AeroCom, Atmos. Chem. Phys., 6, 1777-1813, doi:10.5194/acp-6-1777-2006, 2006.

Thompson, A. M., Singh, H. B., and Schlager, H.: Introduction to special section: Subsonic Assessment Ozone and Nitrogen Oxide Experiment (SONEX) and Pollution from Aircraft Emissions in the North Atlantic Flight Corridor (POLINAT 2), J. Geophys. Res.-Atmos., 105, 3595-3603, 2000.

Tilmes, S., Lamarque, J. F., Emmons, L. K., Conley, A., Schultz, M. G., Saunois, M., Thouret, V., Thompson, A. M., Oltmans, S. J., Johnson, B., and Tarasick, D.: Technical Note: Ozonesonde climatology between 1995 and 2011: description, evaluation and applications, Atmos. Chem. Phys., 12, 74757497, doi:10.5194/acp-12-7475-2012, 2012.

Vrekoussis, M., Kanakidou, M., Mihalopoulos, N., Crutzen, P. J., Lelieveld, J., Perner, D., Berresheim, H., and Baboukas, E.: Role of the $\mathrm{NO}_{3}$ radicals in oxidation processes in the eastern Mediterranean troposphere during the MINOS campaign, Atmos. Chem. Phys., 4, 169-182, doi:10.5194/acp-4-169-2004, 2004.

Wauben, W. M. F., VanVelthoven, P. F. J., and Kelder, H.: A $3 \mathrm{D}$ chemistry transport model study of changes in atmospheric ozone due to aircraft NOx emissions, Atmos. Environ., 31, 18191836, 1997.

Weber, B: Comparing model results of vertical distributions of chemical components in the atmosphere, 2nd ACCRI symposium, Arlington, USA, 13-15 December 2011, 2011. 
Whitt, D. B., Jacobson, M. Z., Wilkerson, J. T., Naiman, A. D., and Lele, S. K.: Vertical mixing of commercial aviation emissions from cruise altitude to the surface, J. Geophys. Res.-Atmos., 116, D14109, doi:10.1029/2010jd015532, 2011.
Wilkerson, J. T., Jacobson, M. Z., Malwitz, A., Balasubramanian, S., Wayson, R., Fleming, G., Naiman, A. D., and Lele, S. K.: Analysis of emission data from global commercial aviation: 2004 and 2006, Atmos. Chem. Phys., 10, 6391-6408, doi:10.5194/acp-10-6391-2010, 2010. 